
\section{MEMBANGUN MINAT BACA PADA SISWA SEKOLAHDASAR}

Di era milenial sekarang anak-anak tumbuh dan berkembang dengan segala kemudahan. proses perkembangan anak tidak terlepas dari perkembangan kognitif, afektif dan konatif. Untuk memaksimalkan setiap proses perkembangan tersebut maka anak-anak harus terlibat dalam proses belajar baik di sekolah maupun di rumah. Saat anak-anak memasuki sekolah dasar, segala proses perkembangan dan proses belajar sebagai dasar atau fondasi yang harus di dapat dengan maksimal oleh para siswa-siswi. Salah satu cara belajar yaitu dengan membaca. Mengenalkan dan mendekatkan anak-anak dengan kegiatan membaca buku sejak sekolah dasar merupakan hal yang sangat penting dan dianjurkan. Perilaku-perilaku membaca sejak dini tersebut, secara tdak langsung dapat meningkatkan minat baca siswa yang merupakan salah satu variabel psikologis yang penting untuk keberhasilan siswa dalam menyerap informasi, pengetahuan serta hasil dan prestasi belajar yang baik. Menjadi sebuah tantangan besar di era sekarang agar anak-anak tidak meninggalkan kegiatan membaca buku, dimana buku sebagai jendela ilmu pengetahuan.

Buku ini berangkat dari sebuah temuan hasil penelitian terkait peran keterlibatan orang tua dan konsep diri membaca dalam meningkatkan minat baca siswa. Dalam buku ini di jelaskan kiat-kiat yang bisa dilakukan oleh orangtua dalam meningkatkan minat baca. Kemudian secara internal siswa/i dapat meningkatkan minat baca dengan membentuk dan mengembangkan konsep diri membaca yang positif.

Dengan membaca buku ini, harapannya para orangtua, guru dan berbagai aspek yang terlibat didalamnya agar sudah siap dan berupaya untuk lebih fokus dalam membimbing dalam mengarahkan anak-anak agar memiliki minat baca yang tinggi sejak dini untuk keberhasilan dimasa yang akan datang.

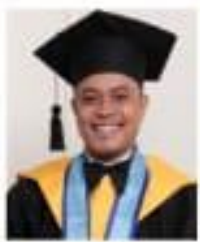

Roy Gustaf Tupen Ama, melanjutkan kuliah di program studi psikologi di Sekolah Tinggi Psikologi Yogyakarta dan lulus pada tahun 2017. Penulis melanjutkan program studi S2 Psikologi dengan konsentrasi psikologi pendidikan di program pasca sarjana, fakultas psikologi, Universitas Mercu Buana Yogyakarta dan lulus pada tahun 2020. Pengalaman pengajar penulis, yaitu sebagai pengajar di Lembaga pendidikan dan pengembangan profesi indonesia (LP3i) College di kupang pada tahun 2017, tercatat sebagai Dosen Tidak tetap di Sekolah Tinggi Psikologi Yogyakarta dan sekarang aktif sebagai pengajar di Lembaga pendidikan dan pengembangan profesi indonesia (LP3I) College Yogyakarta

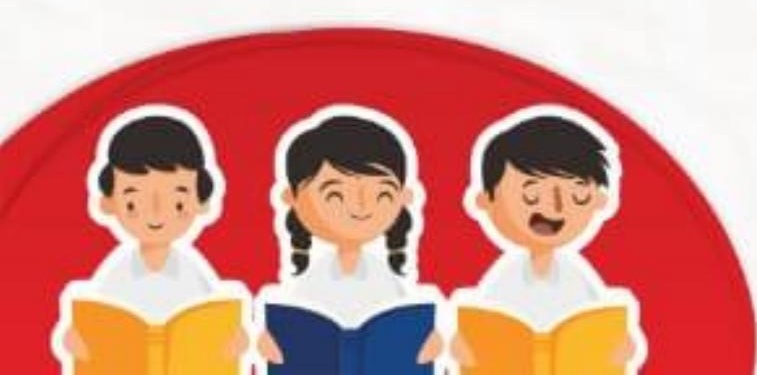

Roy Gustaf Tupen Ama, S.Psi., M.Psi.
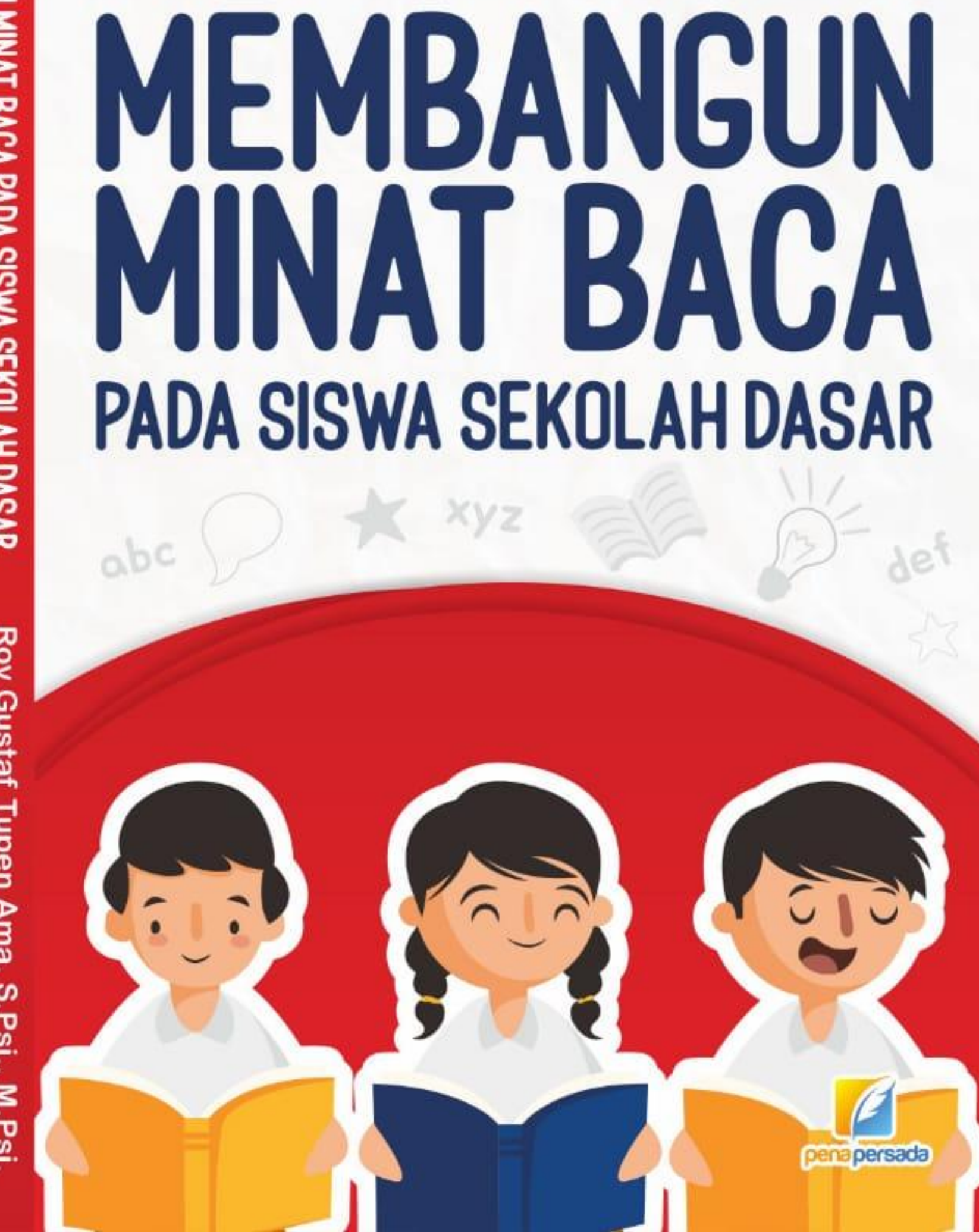


\section{MEMBANGUN MINAT BACA PADA SISWA SEKOLAH DASAR}

ROY GUSTAF TUPEN AMA, S.Psi., M.Psi.

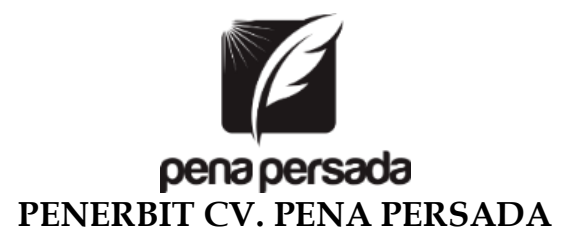




\title{
MEMBANGUN MINAT BACA PADA SISWA SEKOLAH DASAR
}

\author{
Penulis: \\ Roy Gustaf Tupen Ama, S.Psi., M.Psi. \\ ISBN : 978-623-315-121-4 \\ Editor: \\ Tri Hidayati \\ Design Cover : \\ Retnani Nur Briliant \\ Layout : \\ Nisa Falahia \\ Penerbit CV. Pena Persada \\ Redaksi : \\ Jl. Gerilya No. 292 Purwokerto Selatan, Kab. Banyumas \\ Jawa Tengah \\ Email : penerbit.penapersada@gmail.com \\ Website : penapersada.com Phone : (0281) 7771388 \\ Anggota IKAPI \\ All right reserved \\ Cetakan pertama : 2020
}

Hak Cipta dilindungi oleh undang-undang. Dilarang memperbanyak karya tulis ini dalam bentuk apapun tanpa izin penerbit 


\section{KATA PENGANTAR}

Puji syukur saya panjatkan kepada Tuhan Yang Maha Esa, karena atas berkat dan rahmat-Nya, saya dapat menyelesaikan buku ini. Penulisan buku merupakan buah karya dari pemikiran penulis yang diberi judul "Membangun minat baca pada siswa Sekolah Dasar". Saya menyadari bahwa tanpa bantuan dan bimbingan dari berbagai pihak sangatlah sulit bagi saya untuk menyelesaikan karya ini. Oleh karena itu, saya mengucapkan banyak terima kasih pada semua pihak yang telah membantu penyusunan buku ini. Sehingga buku ini bisa hadir di hadapan pembaca.

Kajian dalam buku ini bertujuan untuk mengetahui hubungan antara konsep diri membaca dan persepsi keterlibatan orang tua dalam pendidikan secara bersama-sama dengan minat baca pada siswa. Sumbangan efektif persepsi keterlibatan orang tua dalam pendidikan dan konsep diri membaca secara bersamasama dengan minat baca adalah 75,5\% sedangkan 24,5\% ditentukan oleh variabel lain tidak diukur dalam kajian ini.

Dengan adanya temuan pada kajian ini, sekolah diharapkan mampu untuk menumbuhkan dan meningkatkan minat baca dengan cara membentuk konsep diri membaca yang positif sejak di sekolah dasar dengan membiasakan siswa-siswi melalui kegiatan-kegiatan seperti lomba membaca buku, lomba mendongeng dan lian-lain dengan memberikan reward jika siswa berhasil dalam membaca, jika belum berhasil diberikan punishment positif agar siswa terus belajar mejadi yang terbaik dalam hal membaca. Selain itu sekolah dapat melakukan sosialisasi dengan orang tua siswa akan pentingnya keterlibatan orang tua dalam menumbuhkan minat baca siswa. Untuk itu bagi sekolah perlu diperdalam dan menjalankan program literasi yang dikembangkan di sekolah, hal ini urgen untuk disosialisasikan kepada orang tua sehingga orang tua bisa memahami program yang didapatkan oleh anak mereka di sekolah, sehingga mereka memahami bagaimana berkontribusi untuk mendukungnya. Partisipasi orang tua memerlukan perhatian khusus dan serius, karena pihak sekolah harus mampu menyesuaikan waktu, keahlian, 
pengalaman, dan ketersediaan maupun memastikan bahwa benar adanya komitmen orang tua dengan program literasi salah satunya budaya membaca yang dikembangkan di sekolah.

Penulis menyadari bahwa buku ini masih jauh dari kesempurnaan. Oleh karena itu kritik dan saran yang membangun sangat dibutuhkan guna penyempurnaan buku ini. Akhir kata saya berharap Tuhan Yang Maha Esa berkenan membalas segala kebaikan semua pihak yang telah membantu. Semoga buku ini akan membawa manfaat bagi pengembangan ilmu keperawatan. 


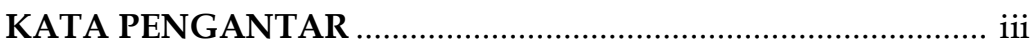

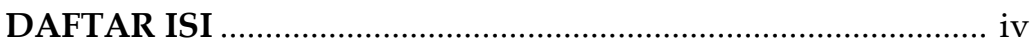

BAB I PENDAHULUAN …….................................. 1

A. Persoalan Minat Baca ……............................................. 1

B. Ketrampilan Membaca ...................................................... 5

C. Persoalan Konsep Diri Membaca ...................................... 8

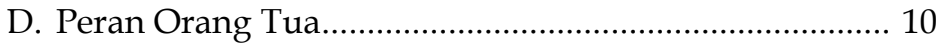

E. Teori Perkembangan Anak .............................................. 12

BAB II

TEORI TENTANG MINAT BACA DAN KONSEP DIRI

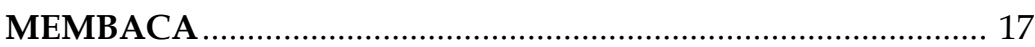

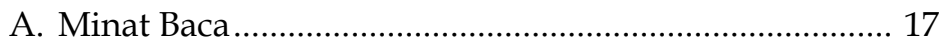

1. Pengertian Minat Baca ................................................ 17

2. Aspek-aspek Minat Baca............................................. 21

3. Faktor-Faktor yang mempengaruhi Minat Baca ...... 23

B. Konsep Diri Membaca..................................................... 28

1. Pengertian Konsep Diri Membaca .............................. 28

2. Aspek-aspek konsep diri Membaca ........................... 30

C. Persepsi Keterlibatan Orang Tua dalam Pendidikan .... 31

1. Pengertian Persepsi Keterlibatan Orang Tua dalam

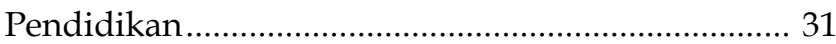

2. Aspek-Aspek Persepsi Keterlibatan Orang Tua dalam Pendidikan ....................................................... 34

BAB III.

HUBUNGAN KONSEP DIRI MEMBACA DAN PERSEPSI

ORANG TUA TERHADAP MINAT BACA............................... 37

A. Hubungan Antara Konsep Diri Membaca dengan Minat Baca ........................................................................ 37

B. Hubungan Antara Pesepsi Keterlibatan orang tua dalam pendidikan dengan Minat Baca.....

C. Hubungan Antara Konsep Diri Membaca dan Persepsi Keterlibatan Orang Tua dalam Pendidikan dengan

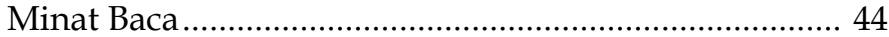

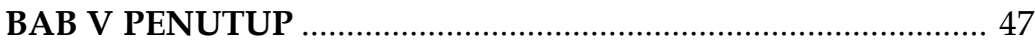

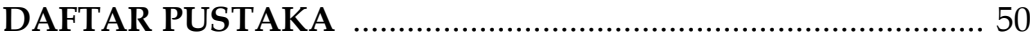




\section{MEMBANGUN MINAT BACA PADA SISWA SEKOLAH DASAR}




\section{BAB I \\ PENDAHULUAN}

\section{A. Persoalan Minat Baca}

Seiring dengan perkembangan IPTEK pada Era millennial, maka berbagai Cara dan strategi terus dilakukan untuk meningkatkan kualitas pendidikan, karena pendidikan selalu mengalami perkembangan dari tahun ke tahun atau dari masa ke masa. Pendidikan juga merupakan instrumen yang sangat luas dan sangat penting, dalam pendidikan tersebut memuat pengetahuan dan nilai -nilai yang terkandung di dalamnya (Surya, 2013). Pendidikan tidak terlepas dari proses belajar. Belajar merupakan proses multidimensional yang melibatkan interaksi yang di dalamnya ada minat dan motivasi yang memuat nilai, tujuan, keyakinan dalam belajar serta dipengaruhi oleh proses kognitif (Chen, Zhu dan Chen, 2014).

Hal ini sesuai dengan tujuan pendidikan nasional yang tertuang dalam Undang-undang Sistem Pendidikan Nasional nomor 20 tahun 2003 sebagai berikut (Surya, 2010):

"Prinsip penyelenggaraan pendidikan adalah dengan mengembangkan budaya membaca, menulis dan berhitung bagi segenap warga masyarakat".

Di sini terlihat jelas bahwa dalam penyelenggaraan pendidikan perlu adanya pengembangan budaya dalam belajar, dan salah satu yang perlu dikembangkan seperti yang dipaparkan dalam undang-undang tersebut ialah membaca.

Dalam meningkatkan minat baca pemerintah sebenarnya telah menerbitkan peraturan baru, yakni dalam peraturan menteri pendidikan dan kebudayaan (Permendikbud) Nomor 23 Tahun 2015 tentang Penumbuhan Budi Pekerti dengan dilaksanakanya wajib membaca 15 menit sebelum waktu pembelajaran dimulai, khususnya bagi siswa SD, SMP atau SMA. Pada tahun 2017, presiden Republik Indonesia, Joko Widodo, telah menandatangani Peraturan Presiden No. 87 
(2017) tentang Penguatan Pendidikan Karakter (PPK-Penguatan Pendidikan Karakter). PPK adalah untuk membiasakan sikap dan perilaku positif di sekolah mulai dari hari pertama sekolah.

Sejalan dengan PPK, Kementerian Pendidikan dan kebudayaan mengembangkan GERNAS BAKU (Gerakan Nasional Orang Tua Membacakan Buku), yang melibatkan semua pemangku kepentingan kebijakan pendidikan, baik di lingkungan pendidikan internal (pusat, provinsi, kota / kabupaten hingga tingkat unit pendidikan) dan lingkungan masyarakat dan orang tua untuk menumbuhkan minat dan gemar membaca pada anak-anak. Akan tetapi pada kenyataannya hal ini belum memberikan dampak yang baik terhadap peningkatan minat baca di Indonesia. Rendahnya minat baca di sini menunjukkan bahwa peserta didik kurang menyenangi buku, memiliki minat baca rendah dan mereka lebih suka menonton televisi (Kartika, 2010).

Menurut Badan Pusat Statistik Indonesia (BPS), survei yang dilakukan pada tahun 2015 menunjukkan bahwa 91,47\% anak usia sekolah lebih suka menonton televisi dan 13,11\% anak usia sekolah yang lebih suka membaca (Kementerian Pendidikan dan Kebudayaan, 2018). Secara umum, berdasarkan data dari Badan Pusat Statistik tahun 2012 menujukkan bahwa sebanyak 91,58 persen masyarakat Indonesia yang berusia 10 tahun ke atas lebih suka menonton televisi dan hanya sekitar 17,58 persen saja masyarakat yang gemar membaca buku, surat kabar, atau majalah. Kemajuan teknologi informasi dan komunikasi telah menjadi penghalang minat anak-anak dalam membaca. Media digital saat ini telah berhasil menjadi pengalih perhatian bagi anak-anak Indonesia saat ini. Hal itu bisa dilihat dari kegiatan sehari-hari mereka yang lebih sering dihabiskan di depan televisi dan gadget karena media lebih menarik bagi mereka (Yaumi, 2014)

Melihat situasi ini seharusnya menjadi perhatian khusus bagi semua pelajar dan yang terlibat dalam proses pendidikan dalam meningkatkan kualitas dan kecakapan dalam belajar. Kualitas dan kecakapan belajar dapat ditingkatkan dengan cara 
meluangkan waktu untuk membaca. Sehingga jika terus dilakukan akan membiasakan diri dan menciptakan minat dalam membaca. Pada aspek kesadaran akan manfaat membaca ditengarai 8 siswa tidak bersemangat membaca buku, memilih bercerita, mengganggu teman sebangku, hanya membolak-balikan halaman buku yang belum selesai dibaca dan guru selalu memberikan perintah dan dorongan untuk membaca. Pada aspek perhatian siswa terhadap buku bacaan ditengarai 5 siswa saat guru memberikan tugas membaca hanya bertahan sekitar 3 sampai 5 menit, kemudian didapati konsentrasi siswa bukan kepada buku bacaan melainkan dengan teman sebangku untuk saling bercanda yang kemudian ditegur oleh guru atas perilaku siswa tersebut. Pada aspek kesenangan membaca buku ditengarai 4 siswa saat diminta guru untuk membaca terlihat mengeluh dan kesal dengan menopang dagu karena guru memberikan tugas membaca.

Berdasarkan hasil pengamatan pada siswa kelas 3, 4, dan 5 yang dijelaskan di atas dapat disimpulkan bahwa minat baca pada siswa kelas 3, 4, dan 5 SDN " $X$ " di Sleman. masih tergolong rendah rendah yaitu tidak memiliki kesadaran sendiri dalam membaca buku, perhatian yang rendah dalam membaca buku baik di sekolah apalagi di rumah, tidak menunjukkan kesenangan saat membaca buku dan frekuensi membaca buku yang rendah karena jarang membaca buku baik di sekolah dan di rumah

Guru mengungkapkan siswa cepat bosan saat diberikan tugas membaca oleh guru, jika tidak di suruh atau diperintah untuk membaca maka siswa tidak melakukan aktivitas membaca, terdapat siswa yang hanya mau membaca buku jika diberikan tugas ataupun latihan soal di kelas tanpa kesadaran sendiri, saat jam kosong atau guru tidak hadir siswa tidak memanfaatkan waktu untuk membaca atau pergi ke perpustakaan sekolah melainkan bermain dan pergi ke kantin sekolah. Guru mengeluhkan bahwa sejauh ini, masih kurangnya peran dari orang tua siswa/i dalam kegiatan belajar terutama membiasakan budaya membaca di rumah. Orang tua 
beranggapan bahwa anak-anak mereka yang disekolahkan di sekolah tersebut sepenuhnya dititipkan dan dipasrahkan sepenuhnya kepada guru, padahal guru mengharapkan dalam membiasakan budaya membaca bukan hanya guru yang terlibat tetapi perlu peran dan keterlibatan orang tua dalam proses belajar di rumah khususnya dalam membiasakan anak gemar dan rajin membaca buku. Berdasarkan hasil wawancara dengan guru tersebut diatas, dapat disimpulkan bahwa rendahnya minat baca siswa Sekolah Dasar karena kurangnya keterlibatan orang tua dalam pendidikan anak.

Mokoagow (2016) mengatakan bahwa individu diharapkan memiliki minat baca yang tinggi karena dengan minat baca yang tinggi akan mampu menyerap berbagai informasi dan ilmu pengetahuan. Kemampuan serta minat baca yang tinggi adalah modal dasar untuk keberhasilan siswa dalam berbagai mata pelajaran serta kemajuan dalam pendidikan.

Kajian tentang minat baca perlu dilakukan karena minat baca yang tinggi penting dalam keberhasilan belajar. Minat baca memiliki dampak dan pengaruh yang baik bagi siswa dalam proses belajar. Berdasarkan hasil penelitian Sabriyadi (2015) bahwa ada hubungan yang signifikan antara minat baca dengan prestasi belajar. Marlina dan Mahdum (2017) dalam penelitiannya menghasilkan bahwa ada hubungan signifikan antara minat baca dengan hasil belajar. Siswa memiliki minat baca dalam proses belajar mengajar akan cepat mengerti dan mudah mengingat setiap pelajaran sehingga menghasilkan hasil belajar dan prestasi yang baik. Minat baca yang ada pada siswa akan menjadikannya lebih tahu dan paham terhadap materi pelajaran. Siswa yang mempunyai hasrat atau keinginan untuk membaca akan mempunyai wawasan yang luas, karena selalu mendapatkan hal-hal terbaru dari hasil bacaannya. Hal ini juga sejalan dengan penelitian yang dilakukan oleh Adam (2017) bahwa minat baca memiliki hubungan yang sangat signifikan dengan prestasi belajar. Semakin tinggi minat baca maka semakin tinggi pula prestasi belajar siswa. Dari penelitian 
di atas disimpulkan bahwa jika seorang siswa memiliki minat baca yang tinggi maka akan di ikuti pula dengan prestasi belajar yang tinggi dan sebaliknya, jika siswa memiliki minat baca yang rendah maka prestasi belajar pun ikut rendah.

Berdasarkan data khusus berupa hasil wawancara dan observasi yang telah dijelaskan sebelumnya yang diperoleh di SDN "X" Sleman pada siswa kelas 3, 4, dan 5 dan guru wali kelas serta kepala sekolah dapat disimpulkan bahwa minat baca menjadi sebuah permasalahan sedang yang terjadi pada siswa-siswa tersebut. Devi dan Shanti (2004), menambahkan bahwa pada usia 6-12 tahun yaitu saat anak memasuki masa kanak-kanak adalah masa yang tepat untuk mulai mengembangkan minat membaca pada anak. Pada usia ini, kemampuan anak memahami bahasa dalam buku bacaan berkembang dengan pesat. Menurut Kartono (1995), bahwa usia (7-13 tahun) ini merupakan usia SD, mulai memandang semua peristiwa dengan objektif, unsur intelektual (kognitif) dan akal budi (moral) terjalin semakin menonjol dan emosionalitas menjadi berkurang. Semua kejadian ingin diselidiki dengan tekun dan penuh minat.

Faktor-faktor yang mempengaruhi minat baca berasal dari faktor internal dan eksternal. Faktor internal yang mempengaruhi minat baca yaitu, intelegensi, kemampuan membaca, sikap terhadap membaca (Haris dan Sippay, 1980), konsep diri (Denessen, Ecless dan Zareet, 2007), usia, jenis kelamin (Stoodt, 1996). Kemudian, Menurut Lamb \& Arnold (dalam Rahim, 2008), faktor-faktor eksternal yang mempengaruhi minat baca yaitu fisiologis, Intelegensi, lingkungan yang meliputi latar belakang dan pengalaman individu di rumah dan faktor sosial ekonomi.

\section{B. Keterampilan Membaca}

Salah satu cara terbaik untuk belajar yaitu dengan membaca. Menurut Susilowati (2016) membaca adalah keterampilan yang harus dimiliki oleh semua praktisi pendidikan. Membaca merupakan kunci dasar yang harus 
dilakukan oleh seorang pelajar jika dia ingin meraih prestasi dalam belajar, karena dengan membaca akan menambah wawasan serta ilmu pengetahuan. Selain itu membaca akan menjadikan individu yang berkualitas.

Bagi seorang pelajar dengan membaca akan memudahkan untuk mencapai prestasinya. Tidak semua pelajar akan mudah memahami apa yang dibacanya. Salah satu faktor yang harus dimiliki seorang pelajar ketika membaca yaitu minat. Minat berhubungan dengan perasaan senang terhadap sesuatu, sehingga minat akan mendorong seseorang untuk melakukan apa yang diinginkannya (Hurlock, 2013). Hal ini disebabkan adanya ketertarikan dari dalam diri seseorang terhadap suatu hal yang ia pelajari. Ketika seorang siswa belajar dengan membaca yang kemudian didasari rasa suka terhadap bacaannya, maka rasa ingin tahu timbul semakin kuat sehingga hasil dari belajarnya dapat dengan mudah dikuasai (Budiyarti, 2012)

Menurut Slameto (2015), minat ialah rasa suka dan rasa keterkaitan pada suatu hal atau aktivitas tanpa ada perintah dari orang lain. Perasaan senang akan menimbulkan minat pula, yang diperkuat lagi oleh sikap yang positif, sebaliknya perasaan yang tidak senang menghambat dalam belajar karena tidak melahirkan sikap yang positif dan tidak menunjang minat dalam belajar. Minat Baca adalah keinginan yang kuat dimiliki individu yang di ikuti dengan usaha-usaha dalam proses membaca (Rahim, 2008). Aspek -aspek minat baca yang harus dimiliki seorang siswa adalah kesadaran akan manfaat membaca, perhatian terhadap membaca, rasa senang dalam membaca dan frekuensi membaca. (Harris \& Sippay (dalam Nursalina, 2014)

Di Indonesia masih tergolong lemah jika dilihat dari budaya membaca. Menurut hasil survey UNESCO (United Nations Educational Scientific and Cultural Organization) yang dimuat dalam website www.gobekasi.pojoksatu.id pada tanggal 19 Mei 2016 bahwa minat baca masyarakat Indonesia baru 0,001 
persen. Artinya, dari setiap seribu orang Indonesia hanya ada satu orang saja yang memiliki minat membaca.

Survei yang dilakukan oleh Central Connecticut State University mengenai budaya literasi menempatkan Indonesia pada urutan ke-60 dari 61 negara yang disurvei, Indonesia hanya berada setingkat lebih baik dari Bostwana. Adapun hasil survei tersebut menempatkan negara seperti, Finlandia, Norwegia, Islandia, Denmark, dan Swedia sebagai lima negara dengan tingkat budaya literasi terbaik di dunia (Central Connecticut State University, 2016). Hasil ini juga menunjukkan bahwa minat membaca buku pada masyarakat Indonesia sangat rendah bila dibandingkan dengan negara berkembang lainnya. Hal ini sejalan dengan studi yang dilakukan oleh Rachman dan Rachmawati (2017) mengenai studi kasus minat baca pada siswa Sekolah Dasar menghasilkan bahwa minat baca siswa kelas 3 Sekolah Dasar Negeri Anyelir 1 Depok tergolong masih rendah, hal ini terlihat dari hasil survei yang dilakukan kepada seluruh siswa kelas 3 dengan jumlah sampel 154 menunjukkan secara keseluruhan tidak lebih dari 55\% siswa yang melakukan kegiatan membaca. Namun demikian, $55 \%$ siswa menyatakan bahwa membaca merupakan kegiatan yang telah dilaksanakan sejak dahulu. Penelitian yang dilakukan oleh Antari, Sundari dan Wulan (2016) mengenai studi deskriptif minat baca siswa SD di kota tangerang menghasilkan bahwa kategori minat baca siswa berada pada kategori rendah sebanyak $40 \%$ dan kategori sedang sebanyak $69 \%$. Rendahnya minat baca tersebut dikarenakan kesadaran membaca, kesenangan membaca dan kebiasaan membaca yang rendah.

Hal di atas sejalan dengan fenomena yang penulis temukan di lapangan terkait minat baca. Pada aspek kesadaran akan membaca ditengarai masih rendah, siswa mengatakan bahwa jika disuruh orang tua ataupun guru barulah siswa tersebut mau membaca buku. Siswa lain mengatakan bahwa karena disuruh dan dipaksa guru untuk membaca sehingga siswa mau tidak mau terpaksa untuk membaca buku di kelas 
karena takut dimarahi oleh guru. Saat berada di rumah siswa mengatakan memilih nonton TV daripada membaca buku karena orang tua tidak menyuruh untuk membaca. Siswa lain mengatakan saat di rumah orang tua jarang melakukan kegiatan membaca buku sehingga siswa mengatakan tidak perlu untuk membaca buku karena orang tua juga tidak membaca buku. Pada aspek perhatian yaitu sejauh mana siswa memiliki perhatian dan ketertarikan dalam membaca ditengarai terdapat siswa yang memiliki perhatian yang rendah dalam membaca buku, siswa mengatakan saat membaca sering tidak berkonsentrasi dan tidak fokus dalam membaca buku apalagi membaca buku-buku pelajaran dan pengetahuan. Siswa mengatakan biasanya meminta temanya membacakan isi bacaan dari buku tersebut kemudian di jelaskan kembali kepada siswa tersebut mengenai isi bacaan tersebut karena perhatian yang rendah terhadap isi bacaan. Pada aspek rasa senang yaitu seberapa besar rasa senang subjek terhadap kegiatan membaca ditengarai siswa mengatakan cepat bosan saat membaca buku, aktivitas luang di rumah siswa tersebut memilih untuk bermain games bersama teman-teman atau tetangga rumah. Siswa yang lain mengatakan bahwa saat ada jam kosong di kelas siswa memilih untuk bercerita dan bercanda bersama teman-teman di kelas daripada ke perpustakaan untuk membaca buku. Pada aspek frekuensi yaitu mengungkap seberapa sering subjek melakukan aktivitas membaca buku ditengarai siswa jarang membaca buku, siswa mengatakan melakukan aktivitas membaca hanya pada saat mau ujian atau diberikan tugas dari guru dan disuruh oleh guru untuk membaca. Siswa mengatakan malas untuk mengunjungi perpustakaan sekolah untuk membaca buku saat waktu luang.

\section{Persoalan Konsep Diri Membaca}

Faktor internal yang dipilih dalam kajian ini yaitu konsep diri membaca yang dimunculkan berdasarkan teori Chapman dan Thummer (1995). Sejalan dengan teori tersebut, 
Konsep diri membaca dipilih sebagai faktor internal karena berdasarkan hasil penelitian Melekoğlu dan Wilkerson (2013) menemukan bahwa konsep diri membaca yang positif akan mempengaruhi perilaku membaca siswa. Hal ini sejalan dengan penelitian yang dilakukan Walgermo, Foldnes, Uppstand dan Solheim (2018) bahwa siswa yang memiliki konsep diri membaca yang positif akan memberikan dampak terhadap tingginya minat baca siswa. Penelitian yang dilakukan oleh Viljantra, Kiuru, Lerkkanen, Silinskas, Poikkeus, dan Nurmi (2016) menunjukkan hasil yang berbeda dari penelitian sebelumnya bahwa siswa dapat memiliki konsep diri membaca yang positif namun dapat juga memiliki minat baca yang rendah dan sebaliknya siswa dapat memiliki konsep diri membaca negatif namun memiliki minat baca yang tinggi. Dalam hal ini, konsep diri yang dimaksud adalah konsep diri membaca yang merupakan suatu bagian atau sub area dari konsep diri akademik. Chapman dan Tunmer (1997) mengatakan bahwa konsep diri membaca adalah gambaran tentang diri atau penilaian diri seseorang dalam proses membaca dengan mengkombinasikan proses persepsi kompetensi dalam melakukan tugas membaca, sulit atau mudah dalam proses membaca dan sikap dirasakan terhadap membaca. Aspek - aspek konsep diri membaca mencakup persepsi kompetensi membaca, persepsi kesulitan membaca serta sikap terhadap membaca (Chapman dan Tumner, 1995).

Konsep diri sendiri terbentuk dari berbagai kesan yang diterima oleh seseorang (Dayakisni, 2006). Persepsi diri pada perilaku khusus mempengaruhi konsep diri sub area (seperti matematika, penelitian sosial) yang kemudian akan mengacu pada konsep diri akademik. Konsep diri membaca merupakan sub area dari konsep diri akademik (Marsh, 1985). Individu yang memiliki konsep diri membaca yang positif ditunjukkan dengan memiliki kompetensi dalam proses membaca, adanya persepi yang positif dalam menghadapi kesulitan membaca dan sikap yang positif saat dihadapkan dalam aktivitas membaca (Chapman dan Turner, 1995). Penelitian yang 
dilakukan Kraayenoord dan Schneider (1999) bahwa konsep diri membaca siswa berhubungan dengan minat baca siswa. Siswa yang memiliki konsep diri membaca yang positif akan mempunyai minat yang tinggi pula terhadap membaca. Ketika siswa memiliki konsep diri membaca yang negatif, maka siswa tersebut akan memiliki minat baca yang rendah pula.

\section{Peran Orang Tua}

Selanjutnya faktor eksternal yang dipilih dalam kajian ini yaitu faktor lingkungan keluarga dengan berfokus pada peran atau keterlibatan orang tua. Keterlibatan orang tua dipilih berdasarkan teori lamb \& arnold (Rahim, 2008) yang menjelaskan bahwa faktor-faktor yang mempengaruhi minat baca siswa adalah lingkungan keluarga yang didalamnya mencangkup peran dan keterlibatan orang tua. Hal ini sejalan dengan pendapat Harras (dalam Sutini, 2010), mengatakan bahwa diantara berbagai faktor eksternal membaca, pengaruh peran dari keluargalah yang sangat tinggi kontribusinya dalam mempengaruhi terbentuknya minat serta kemahiran membaca pada anak. Selain itu keterlibatan orang tua dipilih sebagai faktor ekternal dalam kajian karena berdasarkan temuan dilapangan yang telah dijelaskan sebelumnya bahwa pihak sekolah mengharapkan orang tua berperan dan terlibat dalam menumbuhkan minat baca. Guru mengeluhkan bahwa sejauh ini, masih kurangnya peran dari orang tua siswa/i dalam kegiatan belajar terutama membiasakan budaya membaca di rumah. Orang tua beranggapan bahwa anak-anak yang disekolahkan di sekolah tersebut sepenuhnya dititipkan dan dipasrahkan sepenuhnya kepada guru, padahal guru mengharapkan dalam membiasakan budaya membaca bukan hanya guru yang terlibat tetapi perlu peran dan keterlibatan orang tua dalam proses belajar di rumah khusunya dalam membiasakan anak gemar dan rajin membaca buku. Dalam hal ini beberapa kegiatan yang dapat dilakukan oleh orang tua dirumah adalah seperti, membaca bersama, menyediakan berbagai macam buku bacaan, memberikan anak waktu untuk 
membaca dan lain yang akan menumbuhkan minat baca anak (Hornby, 2018). Hill dan Tyson (2009) mengungkapkan pengertian keterlibatan orang tua dalam pendidikan adalah bentuk interaksi orang tua dengan pihak sekolah dan interaksi antara orang tua dengan siswa di rumah dalam rangka mencapai kesuksesan akademik siswa. Keterlibatan orang tua dalam pendidikan menurut Hill dan Tyon (2009) terdiri dari 3 (tiga) aspek yaitu home-base involvement (keterlibatan di rumah), school-base involvement (keterlibatan di sekolah), dan academik socialization (sosialisasi akademik). Sehingga, keterlibatan orang tua Orang tuayang besar merupakan kunci kesuksesan anak atau siswa/i dalam mengembangkan minat baca serta hasrat untuk terus belajar dan menghasilakn prestasi yang baik.

Rahim (2008) mendefinisikan minat baca sebagai bentuk keinginan yang kuat dimiliki individu yang di ikuti dengan usaha-usaha dalam proses individu membaca sumber bacaan. Minat baca memiliki hubungan dengan variabel lainnya. Salah satunya minat baca berkorelasi dengan Persepsi keterlibatan orang tua. Hoover, Dempsey dan Sandler (2005) dalam studinya mengembangkan model keterlibatan orang tua dimana keterlibatan orang tua dalam bentuk monitoring, penguatan, instruksi serta modeling akan membentuk minat, persepsi diri, ekspektasi, orientasi motivasi, nilai, prestasi, performansi anak. Dalam hal ini persepsi siswa terhadap keterlibatan orang tua memiliki hubungan dengan minat baca siswa sehingga apabila persepsi siswa terhadap keterlibatan orang tua positif maka siswa akan memiliki minat yang tinggi dalam membaca. Penelitian yang dilakukan oleh Rahmi (2019) mengenai keterlibatan orang tua dalam meningkatkan minat baca pada anak menghasilkan bahwa keterlibatan orang tua memiliki hubungan yang positif dan signifikan terhadap minat baca pada anak bahwa jika orang tua terlibat secara positif dalam proses membaca pada anak maka minat baca anak menjadi tinggi. Hal ini senada dengan penelitian yang dilakukan Fakhriyah (2018) bahwa ada hubungan positif antara pesepsi keterlibatan orang tua dengan minat baca siswa sekolah 
dasar. Bahwa semakin positif Persepsi siswa terhadap keterlibatan orang tua maka semakin tinggi minat baca siswa. Hal tersebut menunjukkan bahwa dengan adanya persepsi siswa yang positif terhadap keterlibatan orang tua dalam membaca dapat meningkatkan minat baca siswa.

Minat baca merupakan suatu kajian yang telah berlangsung dalam waktu kewaktu dan berbagai penelitian pun telah dilakukan. Keterlibatan orang tua merupakan hal yang sangat berkaitan dengan minat baca yang dalam hal ini akan dikaji berdasarkan persepsi anak terhadap keterlibatan orang tua. Adapun konsep diri membaca memiliki hubungan dengan minat baca siswa.

Buku ini dapat memberikan informasi mengenai persepsi keterlibatan orang tua dalam pendidikan, konsep diri membaca dan minat baca siswa sehingga menambah dan memperkaya referensi ilmu pengetahuan di bidang psikologi secara umum dan psikologi Pendidikan secara khusus. Dengan adanya kajian ini, diharapkan orang tua dapat mengetahui bahwa positifnya persepsi keterlibatan orang tua yang diterima dan dirasakan siswa dari orang tua nya akan memberikan kontribusi terhadap meningkatnya minat baca siswa, sehingga orang tua akan berpartisipasi dan terlibat secara efektif agar minat baca siswa semakin meningkat. Bagi Guru, kajian ini dapat untuk mengetahui prediktor apa saja yang memiliki hubungan dengan minat baca siswa, sehingga bisa dijadikan acuan untuk melakukan tindakan intervensi misalnya sekolah dapat meningkatkan dan mengembangkan konsep diri membaca siswa melalui berbagai kegiatan antara lain, pemberian tugas dalam bentuk membac buku, lomba mengarang dan membaca, dan games-games seputar kegiatan membaca sejak SD.

\section{E. Teori Perkembangan Anak}

Menurut pendekatan Teori Perkembangan kognitif oleh Piaget, anak pada usia 7 sampai dengan 11 tahun, perkembangan kognitifnya sedang berada pada tahap operational konkrit. Pada tahap ini kemampuan berpikir anak 
pada tahap ini digambarkan dengan kemampuan berpikir yang masih terbatas pada hal-hal yang bersifat konkrit atau nyata. Contoh dari tahap ini adalah penggunaan bendabenda yang ada di sekitar anak seperti balon, bunga, kursi, permen dan lain-lain saat guru atau pengajar melatih kemampuan berhitung anak. Benda-benda tersebut adalah hal-hal yang nyata ada di sekitar anak sehingga mereka dapat membayangkan nya secara langsung saat mengoperasikan hitungan angka yang sifatnya lebih abstrak. Pada masa ini, anak sudah mampu melakukan pengurutan dan klasifikasi terhadap objek maupun situasi tertentu. Kemampuan mengingat dan berpikir secara makin meningkat. Anak mampu memahami konsep sebab-akibat secara rasional dan sistematis sehingga mampu dan bisa bisa belajar bahasa, matematika dan membaca. Pada tahapan ini pula sifat "egosentris" menghilang secara perlahan. (Miler, 2011)

Teori perkembangan kognitif Piaget menjelaskan bahwa pembelajaran dibentuk melalui proses skema yang memuat tentang cara mempersepsi kan sesuatu objek, memahami dan berpikir. Salah satu bentuk dari proses anak membentuk skema adalah perspesi terhadap kererlibatan orang tua dalam belajar dimana salah satu cara belajar yaitu membaca. Hubungan yang harmonis antara anak dengan orang tua sangat penting dalam proses perkembangan anak. Suntrok (2007) mengatakan bahwa hubungan kedekatan orang tua serta peran-peran orang tua sangat penting untuk perkembangan anak karena hubungan tersebut akan di lihat mupun dirasakan oleh anak. Hal itu dapat dipahami bahwa bila anak merasa senang dan nyaman berada didekat orang tua, ia akan berusaha untuk selalu dekat dengan orang tua nya dan apapun yang dilakukan orang tua, anak juga ingin melakukannya sehingga minat anak dalam kegiatan itu akan muncul. Hal ini sesuai dengan pendapat Mowb \& Young (dalam Yetti, 2009) yang menyatakan bahwa kegiatan membaca bersama-sama antara orang tua dan anak-anak akan berpengaruh terhadap sikap dan minat membaca anak. 
Sejalan dengan hal itu Chapman (Al-Ajami dan Soeharto, 2014), berpendapat bahwa sentuhan yang tulus dan penuh kasih sayang yang dirasakan anak dapat menjadi stimulus positif bagi aktivitas belajar anak. Aktivitas yang dilakukan anak dalam belajar salah satunya dengan membaca yang melibatkan proses kognitif.

Hal diatas didukung juga oleh pendekatan teori keluarga yang berfokus pada perkembangan keluarga. Mattessich \& Hill (dalam Puspitawati, 2012). Teori Perkembangan Keluarga merupakan multilevel theory yang berhubungan dengan individualis, dan institusi keluarga. Hal-hal yang sering dibahas pada teori ini adalah konsep perkembangan tugas (the Development of task) sepanjang siklus kehidupan keluarga (Family life cycle). Tahapan Perkembangan Keluarga menurut Duvall (dalam Puspitawati, 2012) ada 8 tahapan yaitu: (1) Tahapan perkawinan (married couple), (2) Tahapan mempunyai anak (childbearing), (3) Tahapan anak berumur preschool (Preschool age), (4) Tahapan anak berumur Sekolah Dasar (school age), (5) Tahapan anak berumur remaja (teenage), (6) Tahapan anak lepas dari orang tua (launching center), (7) Tahapan orang tua umur menengah (middle-aged parents) dan (8) Tahapan orang tua umur manula (aging parents).

Teori perkembangan keluarga merupakan teori yang menjelaskan perubahan baik yang terjadi pada individu atau kelompok. Individu, kelompok dan masyarakat mengalami perkembangan melalui tahapan-tahapan yang terjadi sepanjang waktu. Salah satu model teori perkembangan adalah unilinier, yang menganalisis perkembangan atau perubahan institusi dan masyarakat sepanjang waktu.

Proses Perkembangan Keluarga mempunyai beberapa tujuan (related to teleology). Berkaitan dengan perkembangan anak ditandai dengan meningkatnya perkembangan moralitas dan kognitif. Perkembangan moralitas dan kognitif tidak semata-mata didapatkan begitu saja melainkan melalui proses belajar untuk mengembangkan moralitas yang berkaitan 
dengan nilai-nilai yang dianut, serta kognitif berkaitan dengan kemampuan berpikir, menganalisa, dan menilai sesuatu sesuai dengan kemampuan masing-masing. Ada suatu seri tahapan perkembangan individu bermula dari infant/ bayi, anak balita, usia anak-anak (awal, menengah, akhir), usia remaja (awal, menengah, akhir), usia dewasa (awal, menengah, akhir) dan usia lanjut usia (tua, tua sekali, tua renta).

Mattessich \& Hill (dalam Puspitawati, 2012) menjelaskan bahwa perkembangan keluarga (family development) merujuk pada proses perkembangan dan transformasi struktural yang progresif sepanjang sejarah keluarga. Terdapat tiga aspek penting untuk memahami fenomena perkembangan keluarga: (1) memantapkan perkembangan keluarga sebagai organisasi dan fenomena interaksi (2) menekankan hubungan atau kelangsungan perilaku keluarga sepanjang sejarah keluarga dan (3) mencirikan dua sumber perkembangan perubahan, yaitu perubahan syarat fungsional dan timbulnya tekanan hidup. Teori perkembangan keluarga (family development theory) berusaha untuk menjelaskan proses perubahan dalam keluarga. Point dari perspektif perkembangan keluarga adalah perubahan tingkatan keluarga dari waktu ke waktu (family time) yang dipercepat secara internal oleh permintaan anggota keluarga (biologis, psikologis dan kebutuhan sosial) dan secara eksternal oleh masyarakat yang lebih luas (harapan masyarakat dan keterbatasan lingkungan).

Secara keseluruhan konsep diri membaca dan persepsi keterlibatan orang tua dalam pendidikan secara bersama-sama memberikan pengaruh terhadap pembentukan minat baca. Proses berpikir dalam mebentuk skema-skema berkaitan dengan proses kognitif anak dalam pembentukan, pengorganisasian, penilaian anak tentang dirinyanya sendiri dalam kapasitas membaca dalam proses belajar, membentuk konsep diri membaca berdasarkan penilaian terhadap dirinya, yang mendorong timbulnya minat baca anak. Proses 
pembentukan Skema juga memuat unsur persepsi yang didapatkan dari penerapan keterlibatan orang tua yang berdampak pada minat baca. Sehingga peran serta proses persepsi keterlibatan orang tua dan konsep diri membaca pada anak dapat menjadikan anak memiliki minat baca yang tinggi. 


\section{BAB II \\ TEORI TENTANG MINAT BACA DAN KONSEP DIRI MEMBACA}

\section{A. Minat Baca}

\section{Pengertian Minat Baca}

Minat adalah suatu keadaan dimana seseorang mempunyai perhatian terhadap sesuatu dan disertai keinginan untuk mengetahui dan mempelajari maupun membuktikan lebih lanjut. (Walgito,1981). Hurlock (2013) mendefenisikan minat sebagai sumber motivasi yang mendorong orang untuk melakukan apa yang mereka inginkan bila mereka bebas memilihnya. Minat adalah suatu rasa suka dan rasa ketertarikan pada suatu hal atau aktivitas belajar. (Suryabrata, 2016).

Caplin (2006) menjelaskan bahwa minat ialah perasaan yang menyatakan bahwa satu aktivitas, pekerjaan atau objek itu berharga atau berarti bagi individu. Senada dengan beberapa pendapat diatas di atas, Ormrod (2008) mendefinisikan minat sebagai persepsi bahwa suatu aktivitas menimbulkan rasa ingin tahu dan menarik, biasanya disertai oleh keterlibatan kognitif dan afektif yang positif seperti kesenangan, kegembiraan, dan kesukaan. Minat dibedakan atas dua yakni minat situasional dan minat pribadi. Minat situasional adalah minat yang dipicu secara temporer oleh sesuatu di lingkungan sekitar, sedangkan minat pribadi adalah minat yang bersifat jangka panjang dan relatif stabil pada suatu topik atau aktivitas.

Minat Baca adalah keinginan yang kuat dimiliki individu yang di ikuti dengan usaha-usaha dalam proses membaca Seseorang yang mempunyai minat membaca yang kuat akan diwujudkan dalam kesediaannya untuk mendapat bahan bacaan dan kemudian membacanya atas kesadarannya sendiri (Rahim, 2008). Salah satu cara dalam belajar adalah dengan membaca, sehingga siswa harus 
memiliki minta yang tinggi karena tanpa ada minat seorang siswa tidak akan melakukan aktivitas membaca, oleh karena itu minat memiliki pengaruh besar terhadap membaca. Minat membaca siswa dapat dipengaruhi oleh lingkungan keluarga yang berupa persepsi keterlibatan orang tua dan Konsep diri. Peneliti menganalisis hubungan Persepsi keterlibatan orang tua dan Konsep diri membaca dengan minat baca menggunakan perspektif teori kognitif yaitu sebagian proses pembelajaran manusia adalah hasil dari proses kognisi yang saling berhubungan. Perkembangan kognitif bukan hanya hasil kematangan organisme, bukan pula pengaruh lingkungan semata, melainkan hasil interaksi diantara keduanya. Anak dapat membangun secara aktif dunia kognitif mereka sendiri. Dalam pandangan Piaget, terdapat dua proses yang mendasari perkembangan dunia individu, yaitu pengorganisasian dan penyesuaian (adaptasi). Jean Piaget menyebut bahwa struktur kognitif sebagai skemata (Schemas), yaitu kumpulan dari skemaskema. Skema sendiri berarti seperangkat keterampilan, pola pola kegiatan yang flexibel yang dengannya anak akan memahami lingkungan. Seseorang individu dapat mengikat, memahami, dan memberikan respons terhadap stimulus disebabkan karena bekerjanya skemata ini. Sedangkan intelegensi lebih merupakan proses dari pada tempat penyimpanan informasi yang statis. Skemata ini berkembang secara kronologis, sebagai hasil interaksi antara individu dengan lingkungannya. Piaget (yusuf, 2014).

Berdasarkan teori kognitif Piaget dapat disimpulkan bahwa suatu perilaku terbentuk dimulai dengan proses kognitif karena terbentuknya skema-skema dalam proses berpikir, atensi, memori dalam merespons sebuah stimulus. Dalam pembentukan minat baca bahwa terdapat proses membaca yang melibatkan proses kognitif. Spache dan Spache (Petty dan Jensen, 1980) menyebut aktivitas, maupun minat dalam membaca sebagai suatu proses yang sangat kompleks, karena melibatkan proses-proses yang bersifat 
fisik maupun psikis. Ketika membaca, seseorang harus mengaktifkan komponen-komponen psikis seperti perhatian, kemampuan asosiasi, kemampuan mengingat, menelaah, dan menyerap semua bahan bacaan. Bahkan tidak jarang individu juga melakukan proses internalisasi terhadap bahan bacaan tersebut. Thorndike (dalam Heilman. dkk, 1981) juga mengemukakan bahwa membaca, seperti halnya proses berpikir, melibatkan proses pembelajaran, refleksi, penilaian, analisis, sintesis, pemecahan masalah, seleksi, pengambilan keputusan, organisasi, perbandingan, penentuan hubungan, dan evaluasi kritis terhadap isi bacaan. Membaca juga melibatkan perhatian, asosiasi, abstraksi, generalisasi, dan konsentrasi. Sementara itu Anderson dan Pearson (Sumaryono, 1991) menyatakan bahwa aktivitas membaca menuntut pelakunya untuk membuat kesimpulankesimpulan dengan mengintegrasikan pengetahuanpengetahuan yang sebelumnya telah dimilikinya.

Minat Baca terbentuk saat individu miliki kesadaran, perhatian dan kemauan sendiri berdasarkan kemampuan atau kompetensi membaca yang baik dalam dirinya. (Rahim, 2008). Hal ini berhubungan dengan faktor dari dalam diri yaitu konsep diri membaca. Hurlock (2004) mengatakan bahwa konsep diri anak yang dibentuk sejak dini akan membantu anak-anak tersebut menumbuhkan minat terhadap sesuatu pelajaran. Hal ini senada dengan penelitian yang dilakukan oleh (Denessen, Ecless dan Zareet, 2007) mengenai hubungan longitudinal antara konsep diri, minat dalam belajar serta prestasi akademik bahwa konsep diri berkorelasi Positif dalam minat siswa dalam hal ini salah satunya adalah minat dalam membaca yang tertuang dalam aktivitas belajar.

Dari beberapa pendapat di atas, dapat disimpulkan bahwa minat adalah suatu rasa yang lebih suka atau rasa ketertarikan pada suatu kegiatan yang ditunjukkan dengan keinginan, kecenderungan untuk memperhatikan kegiatan 
tersebut tanpa ada seorang pun yang menyuruh, dilakukan dengan kesadaran diri sendiri dan diikuti dengan perasaan yang senang.

Dalam kajian ini penulis berfokus pada minat yang dikaitkan pada proses maupun aktivitas membaca pada siswa. Membaca adalah proses mengenal kata, memadukan arti kata dalam kalimat dan struktur bacaan. Hasil akhir dari membaca adalah seseorang mampu membuat intisari dari bacaan (Juel dalam Sandjaja, 2005). Menurut Tarigan (2008), membaca adalah suatu proses yang dilakukan dan dipergunakan oleh pembaca untuk memperoleh pesan yang hendak disampaikan oleh penulis melalui media kata-kata/ bahasa tulis.

Berdasarkan beberapa pengertian membaca tersebut, maka dapat diartikan bahwa membaca merupakan proses aktivitas komunikasi yang kompleks yang bertujuan untuk melihat, memahami isi atau makna dan memperoleh pesan yang hendak disampaikan penulis melalui media kata-kata atau bahasa tulis sehingga diperoleh pemahaman terhadap bacaan. Orang yang melakukan aktivitas tentunya mempunyai tujuan yang ingin dicapai, demikian juga dalam kegiatan membaca. Seseorang yang membaca dengan suatu tujuan cenderung lebih memahami dibandingkan dengan orang yang tidak mempunyai tujuan. Tujuan dari membaca adalah untuk memperoleh makna yang tepat dari bacaan yang dibacanya. Oleh karena itu akan menjadikan seseorang terus berpikir untuk memahami makna yang terkandung dalam tulisan. Semakin sering banyak seseorang dalam membaca, semakin tertantang untuk terus berpikir terhadap apa yang mereka baca.

Minat baca adalah keinginan yang kuat dimiliki individu yang di ikuti dengan usaha-usaha dalam proses membaca (Rahim, 2008). Minat baca diartikan sebagai sebuah aktivitas dalam bentuk dorongan dalam diri individu dalam memahami kata demi kata dan isi dari sebuah bacaan, dengan penuh ketekunan, kesadaran dan 
rasa senang. (Dalman, 2013). Ginting (2005) memberi pengertian minat baca adalah bentuk- bentuk perilaku yang terarah guna melakukan kegiatan membaca sebagai tingkat kesenangan yang kuat yang dirasakan sebagai hal yang menyenangkan. Darmono (2007) memangatakan bahwa minat baca adalah kecenderungan jiwa yang kuat untuk melalukan kegiatan membaca dengan tujuan tertentu. Menurut Liliawati (dalam Sandjaja, 2005) mengartikan minat baca adalah suatu perhatian yang kuat dan mendalam disertai dengan perasaan senang terhadap kegiatan membaca sehingga dapat mengarahkan seorang untuk membaca dengan kemauannya sendiri.

Berdasarkan uraian di atas maka dapat penulis simpulkan bahwa minat baca adalah keinginan kuat yang timbul dari dalam diri individu disertai dengan usahausaha yang dilakukan oleh individu dalam proses membaca.

\section{Aspek-aspek Minat Baca}

Minat baca seorang siswa dapat dilihat dari aspekaspek minat baca antara lain:

a. Atensi membaca

Saat siswa melakukan kegiatan membaca jika minat baca siswa tinggi maka akan terlihat dari besarnya perhatian yang ditunjukkan dalam membaca, fokus terhadap bacaan serta menunjukkan keseriusan membaca.

b. Kegemaran membaca

Saat siswa memiliki kesukaan atau kegemaran membaca, maka akan terlihat dalam aktivitas misalnya siswa menyukai kegiatan membaca, menjadikan kegiatan membaca menjadi bagian dari hobby yang menyenangkan sehingga miant mmbacapun juga tinggi.

c. Waktu membaca

Siswa yang memiliki minat baca tinggi bisa dilihat dari seberapa banyak waktu yang digunakan dalam 
membaca, ataupun saat waktu luang digunakan untuk membaca maupun memiliki jadwal khusus dalam membaca yang dijadikan sebuah rutinitas yang produktif dalam kegiatan membaca.

d. Jumlah Buku bacaan

Minat baca yang tinggi juga bisa dilihat sejauh mana siswa memiliki koleksi buku-buku bacaan maupun dalam bentuk e-book yang dibaca oleh siswa atapun siswa memiliki kebiasaan membeli buku edisi terbaru atau cetakan terbaru untuk di baca. Siswa-siswa juga memiliki perpustakaan mini di rumah untuk mengoleksi buku yang dibaca.

Menurut Harris \& Sippay (1980) yang juga di jelaskan dan diterjemahkan oleh Nursalina (2014) minat baca dapat dilihat dari :

1) Seberapa jauh subyek menyadari, mengetahui dan memahami manfaat membaca

2) Perhatian dan ketertarikan subjek dalam membaca buku

3) Seberapa besar rasa senang subjek terhadap kegiatan membaca.

4) Seberapa sering subjek melakukan aktivitas membaca buku.

Menurut Hurlock (2013), aspek-aspek minat yang di kaitkan dengan minat baca antara lain:

1) Kesadaran

Seseorang disebut berminat dalam suatu objek, apabila seseorang tersebut memiliki kesadaran. Sebab dengan kesadaran, seseorang dapat mengenal objek yang mempunyai gaya tarik sehingga timbul rasa senan, ingin memiliki bahkan objek tersebut tetap berada dalam dirinya. 
2) Perhatian

Seseorang dikatakan berminat terhadap suatu objek bila di dalamnya disertai perhatian. Perhatian langsung maupun tidak langsung. Perhatian langsung bila individu terhadap objek masih dalam jangkauan indra, sedangkan perhatian tak langsung jika individu merasa tertarik pada suatu objek dengan fungsi panca indra tidak dapat kontak langsung dengan objek yang diamati. Untuk ini yang berfungsi hanya kesadaran individu yang menyebabkan bertambahnya aktivitas dan daya konsentrasi terhadap suatu objek.

\section{Faktor-Faktor yang mempengaruhi Minat Baca}

Faktor-faktor yang mempengaruhi minat baca berasal dari faktor internal dan eksternal. Faktor-faktor internal yang mempengaruhi minat baca terdiri dari intelegensi, kemampuan membaca, sikap terhadap membaca, jenis kelamin (Harris dan Sippay, 1980); konsep diri membaca (Denessen, Ecless dan Zareet, 2007); dan Usia (Stoodt, 1996) yang dijabarkan sebagai berikut :

a. Intelegensi

Pada umumnya anak-anak yang memiliki tingkat kecerdasan yang tinggi aktivitas membaca akan lebih tinggi dibandingkan anak-anak yang kecerdasannya dibawah rata-rata. (Harris \& Sippay, 1980).

b. Kemampuan membaca

Menurut Harris dan Sippay (1980) bahwa kemampuan membaca tidak secara langsung berkorelasi dengan minat baca. Minat sebagai salah satu factor dalam pemahaman secara signifikan penting bagi para pembaca dengan kemampuan membaca yang masih rendah.

c. Sikap terhadap membaca

Pada konteks tertentu sikap seseorang berpengaruh pada minat membacanya. Jika membaca 
dapat memenuhi suatu kebutuhan, sikap positif biasanya akan bertumbuh akan kebutuhan tersebut. Sikap positif ini biasanya mendorong seseorang di dalam meningkatkan minat bacaannya (Harris dan Sippay, 1980).

d. Jenis kelamin

Faktor jenis kelamin berfungsi sebagai pendorong pemilihan buku bacaan dan minat baca siswa. (Haris dan sippay, 1980). Pada umumnya anak-anak perempuan menyukai buku cerita dengan tema kehidupan keluarga dan sekolah sedangkan anak laki -laki lebih menyukai buku cerita mengenai petualangan, kisah misteri, seram, cerita kepahlawanan dan humor. (Munandar, 1986).

e. Konsep diri membaca

Penelitian yang dilakukan oleh (Denessen, Ecless dan Zareet (2007) dengan judul "Hubungan longitudinal antara konsep diri, minat dalam belajar serta prestasi akademik" mengemukakan bahwa konsep diri berkorelasi positif dalam minat siswa dalam hal ini salah satunya adalah minat dalam membaca yang tertuang dalam aktivitas belajar. Hurlock (2004) mengatakan bahwa konsep diri anak yang dibentuk sejak dini akan membantu anak-anak tersebut menumbuhkan minat terhadap sesuatu pelajaran. Penelitian lebih spesifik yang dilakukan oleh Melekoglu \& Wilkerson (2013) mengenai motivasi, minat, serta prestasi membaca menghasilkan kesimpulan bahwa konsep diri membaca memiliki korelasi yang positif dalam motivasi, minat serta prestasi membaca. Hal ini sejalan dengan penelitian walgermo, dkk (2018) mengenai model pengembangan minat baca ditinjau dari konsep diri membaca dan kemampuan membaca menghasilkan bahwa konsep diri membaca yang positif berpengaruh terhadap minat baca. 
f. Usia

Minat membaca seorang siswa biasanya tidak tetap/statis, melainkan selalu berubah seiring bertambahnya usia. Anak-anak yang sejak usia dini dibiasakan membaca menjadi sebuah kebiasaan seiring bertambahnya usia. (Stoodt, 1996).

Faktor-faktor eksternal yang mempengaruhi minat membaca menurut Lamb dan Arnold (dalam Rahim, 2008), antara lain :

1) Faktor fisiologis

Faktor fisiologis mencakup kesehatan fisik, pertimbangan neurologis, dan jenis kelamin. Kelelahan juga merupakan kondisi yang tidak menguntungkan bagi anak untuk belajar, khususnya belajar membaca.

2) Faktor intelegensi

Intelegensi itu sendiri terdiri atas dua macam faktor, yaitu: kemampuan untuk memperoleh pengetahuan dan pengetahuan yang telah diperoleh. Intelegensi memiliki pengaruh yang signifikan dalam proses belajar sehingga menunjang anak untuk mencapai hasil belajar yang baik.

3) Faktor lingkungan

Faktor lingkungan itu mencakup:

a) Faktor latar belakang dan pengalaman individu di rumah.

Hurlock (2004) mengatakan bahwa lingkungan keluarga merupakan faktor penentu anak dalam mengembangkan aktivitas minat mereka salah satunya minta dalam membaca sejak dini. Lingkungan keluarga dapat membentuk pribadi, sikap, nilai, dan kemampuan bahasa individu. Kondisi di rumah mempengaruhi pribadi dan penyesuaian diri individu dalam masyarakat. Kondisi itu pada gilirannya dapat membantu individu, dan dapat juga menghalangi 
individu dalam membaca. Individu yang tinggal di dalam rumah tangga yang harmonis, rumah yang penuh dengan cinta kasih, yang orang tuanya memahami anak-anaknya, dan mempersiapkan seorang individu dengan harga diri yang tinggi, tidak akan menemukan kendala yang berarti dalam membaca. Artinya bahwa orang tua terlibat dalam proses membaca anakanak di rumah. Hornby (2011) menambahkan bahwa lingkungan keluarga memiliki andil yang besar dalam proses belajar anak. Orang tua terlibat dengan menaruh perhatian, membimbing dan memotivasi setiap proses belajar di rumah untuk mendukung kesuksesan akademik anak di ranah pendidikan. Sejalan dengan hal tersebut, Keterlibatan orang tua dalam pendidikan anak akan berpengaruh positif apabila orang tua memahami makna, bentuk dan tujuan keterlibatan tersebut agar mereka dapat memutuskan tindakan yang tepat dalam pendidikan anak mereka di sekolah (Yusuf, 2014). Sehubungan dengan hal tersebut terdapat pendapat Henderson dkk. (dalam Ferara \& Ferara, 2005) bahwa keterlibatan orang tua dalam pendidikan merupakan hal yang sangat penting untuk mendukung belajar anak, baik di sekolah formal maupun di kursus belajar.

b) Faktor sosial ekonomi

Slavin (2011) menemukan ada aktivitas perbedaan orang tua dalam membimbing anak antara status social ekonomi tinggi dan status social ekonomi rendah. Anak-anak yang mendapat contoh bahasa yang baik dari orang dewasa serta orang tua yang berbicara dan mendorong anakanak mereka berbicara akan mendukung perkembangan bahasa dan intelegensi anak. Begitu pula dengan kemampuan membaca 
individu. Individu yang memberikan banyak kesempatan membaca, dalam lingkungan yang penuh dengan bahan bacaan yang beragam akan mempunyai kemampuan membaca yang tinggi. Orang tua dengan status sosial ekonomi rendah sering memberi contoh negatif dalam berbagai aspek kehidupan anaknya, seperti dalam berbicara, terutama saat mereka bertengkar karena keterbatasan keuangan keluarga. Selain itu, mereka juga jarang memuji anak ketika anak membaca, bahkan orang tua memiliki pengharapan rendah terhadap keberhasilan sekolah anak sehingga mereka tidak mau terlibat untuk membantu pekerjaan rumah anak atau tugas sekolah yang lain. Akibat selanjutnya anak menjadi tidak berprestasi di sekolah dan hal ini menambah tekanan keluarga ketika orang tua dipanggil ke sekolah untuk mempertanggungjawabkan kegagalan pendidikan anak. Sehingga keluarga dengan status sosial ekonomi rendah cenderung mengalami stres yang tinggi.

Berdasarkan penjelasan di atas maka faktor-faktor yang mempengaruhi minat baca terdiri dari faktor internal yaitu intelegensi, kemampuan membaca, sikap terhadap membaca, jenis konsep diri membaca dan usia. Faktor-faktor eksternal yang mempengaruhi minat baca meliputi faktor fisiologis, intelektual, lingkungan yang mencangkup latar belakang keluarga dan pengalaman individu di Rumah dan faktor sosial ekonomi. Dari beberapa faktor yang dikemukakan di atas maka peneliti memilih faktor konsep diri membaca dan keterlibatan orang tua sebagai faktor internal dan eksternal dalam kajian ini. Peneliti mengambil konsep diri membaca dikarenakan menurut Chapman dan Thunmer (1997) bahwa anak yang memiliki konsep diri membaca yang positif maka minat baca menjadi tinggi karena selalu menganggap aktivitas membaca sebagai 
hal yang positif. Hal ini dapat dilihat berdasarkan penelitian Fakhriyah (2018) bahwa ada hubungan antara konsep diri dengan minat baca. Konsep diri merupakan faktor internal yang berasal dari dalam diri individu yang mempengaruhi minat baca seseorang. Keterlibatan orang tua merupakan faktor eksternal atau faktor dari luar diri individu yang mempengaruhi minat baca seseorang. Keterlibatan orang tua dihubungkan atau disambungkan dengan persepsi artinya bahwa bagaimana siswa atau individu menilai atau memberi makna terhadap keterlibatan orang tua dalam proses membaca.

\section{B. Konsep Diri Membaca}

\section{Pengertian Konsep Diri Membaca}

Calhoum dan Acocella (1990) mendefinisikan konsep diri sebagai gambaran dari diri atau pribadi seseorang tentang dirinya sendiri. Hurlock (1978) mengatakan bahwa konsep diri adalah bentuk gambaran dari keyakinan yang dimiliki seseorang tentang dirinya meliputi hal-hal seperti karakter fisik, psikologis, social, dan emosional, aspirasi dan prestasi. Konsep diri (self-concept) diartikan sebagai bentuk evaluasi terhadap yang mendalam dan spesifik dari diri dengan bentuk evaluasi seperti-akademik, atletik, penampilan fisik, dan sebagainya (Suntrock, 2003). Menurut Stuart dan Sudeen (1998), konsep-diri merupakan informasi yang dimiliki individu yang berasal dari keyakinan, hasil pemikiran, pendapat, dan prinsip individu yang kemudian akan berdampak pada individu saat berhubungan dengan orang lain. Menurut Burns (1993), konsep-diri adalah bagaimana cara individu bersikap sesuai dengan kepercayaan individu terhadap diri sendiri.

Pada kajian ini berfokus pada konsep diri membaca yang merupakan sub area dari konsep diri akademik. Chapman dan Tunmer (1995) menjelaskan bahwa konsep diri memiliki beberapa sub area salah satunya adalah konsep diri akademik yang di dalam konsep diri akademik memuat konsep diri membaca. Chapman dan Tunmer 
(1997) mendefinisikan konsep diri membaca adalah gambaran tentang diri atau penilaian diri seseorang dalam proses membaca dengan mengkombinasikan proses persepsi kompetensi dalam melakukan tugas membaca, sulit atau mudah dalam proses membaca dan sikap dirasakan terhadap membaca. Quandt dan Selznick (1984) mengatakan bahwa konsep diri membaca adalah sebuah konstruksi dalam diri individu dibuktikan oleh sejumlah perilaku dalam membaca. Konsep diri membaca adalah keseluruhan persepsi diri tentang diri sendiri sebagai pembaca dalam melakukan kegiatan membaca (Conradi. dkk, 2014). Chapman (2000) mendefinisikan konsep diri membaca sebagai persepsi individu terhadap kemampuan membaca di mana individu memandang proses membaca sebagai keterampilan yang penting.

Konsep diri terdiri dari konsep diri positif dan konsep diri negatif. Benner (1985) menjelaskan bahwa Konsep-diri yang positif akan memungkinkan seseorang untuk bisa bertahan menghadapi masalah yang akan dihadapinya, menjadi lebih percaya diri, keren, berharga dan bangga pada diri mereka sendiri sehingga pandangan diri mereka terhadap mereka sendiri menjadi lebih positif dan akan membawa dampak positif juga bagi orang lain di sekitar individu. Sebaliknya, konsep-diri yang negatif merupakan penilaian yang negatif mengenai diri sendiri, individu menilai dirinya sebagai figur yang mengecewakan. Penilaian yang negatif individu terhadap diri sendiri akan cenderung menjadikan individu menolak dirinya sendiri, sehingga individu akan lebih sering kurang percaya diri, menjadi rendah diri dan merasa tidak mampu terhadap dirinya sendiri. Penolakan diri juga dapat memicu munculnya sikap agresif dan perilaku negatif, sehingga individu menjadi tertutup dan kurang tertarik untuk menjalin hubungan sosial dengan orang lain. Efek dari konsep-diri yang negatif ini akan mempengaruhi hubungan interpersonal maupun fungsi mental lainnya bagi individu. 
Konsep-diri ini penting dalam menentukan perilaku seseorang di lingkungannya sehingga mengharapkan seseorang memiliki penilaian positif mengenai dirinya.

Chapman dan Thumnner (1995) menjelaskan bahwa Konsep diri membaca yang positif yang dimiliki oleh individu menjadikan individu memiliki penilaian yang positif tentang dirinya terkait kegiatan membaca yang dilakukan. Individu yang menganggap kegiatan membaca sebagai sebuah aktivitas yang positif yang berdampak baik untuk dirinya sendiri dalam hal membaca. Sebaliknya individu yang memiliki konsep diri membaca yang negatif akan memandang dirinya tidak memiliki kemampuan dan keterampilan membaca yang baik sehingga ada kecenderungan akan menghindari setiap aktivitas yang berhubungan dengan membaca.

Berdasarkan definisi-definisi di atas, Penulis simpulkan bahwa konsep-diri membaca adalah penilaian diri dalam proses membaca yang melibatkan proses persepsi kompetensi dalam melakukan tugas membaca, sulit atau mudah dalam proses membaca dan sikap dirasakan dalam proses membaca.

\section{Aspek-aspek konsep diri Membaca}

Menurut Chapman dan Tunmer (1995) aspek-aspek konsep diri membaca sebagai berikut:

a. Kompetensi Membaca

Hal ini berkaitan dengan mengacu pada keyakinan individu terhadap dirinya sendiri dalam menilai tentang kemampuan dan kecakapannya dalam proses dan tugas membaca.

b. Persepsi Kesulitan membaca

Persepsi kesulitan mengacu pada keyakinan bahwa kegiatan membaca itu terkadang ada kesulitannya, atau bermasalah, Ketika anak-anak dapat memiliki persepsi diri yang positif tentang proses 
membaca maka anak akan mampu mengatasi dan melalui kesulitan membaca tersebut.

c. Sikap membaca

Sikap mengacu pada komponen afektif dalam membaca, yang digambarkan dalam hal perasaan dan afinitas untuk membaca. Sikap ini menunjuk pada perasaan atau keadaan afektif siswa dalam memandang aktivitas membaca. Sejalan dengan pendapat chapman dan Tunmer (1995), Ajzen (2005) menjelaskan bahwa sikap terhadap membaca merupakan perasaan suka atau tidak suka terhadap aktivitas membaca berdasarkan konsep dan informasi yang telah diketahui namun masih merupakan sebuah kesiapan untuk melakukan kegiatan membaca.

Calhoun dan Acocella (1995) menjabarkan konsep diri terdiri dari tiga dimensi yang dijabarkan sebagai berikut:

a. Pengetahuan

Pengetahuan berkaitan dengan apa yang kita ketahui tentang diri kita, termasuk dalam hal ini jenis kelamin, suku bangsa, pekerjaan, usia dan sebagainya. Pengetahuan ini diperoleh individu dengan cara membandingkan dirinya dengan kelompok pembanding nya. Pengetahuan ini bisa dirubah dengan cara mengubah tingkat laku individu tersebut atau dengan cara mengubah kelompok pembanding nya.

b. Pengharapan

Setiap individu memiliki harapan yang berbedabeda bagi dirinya sendiri. Harapan dapat menjadi seseorang menjadi semangat dan gigih dalam mendorong seseorang untuk mencapai harapan tersebut di masa depan.

c. Penilaian

Penilaian menyangkut seberapa besar seseorang menyukai diri kita sendiri. Semakin besar ketidaksesuaian antara gambaran kita tentang diri kita yang 
ideal (ideal self) dan yang actual maka akan semakin terendah harga diri kita. Sebaliknya orang yang memiliki harga diri yang tinggi akan menyukai siapa dirinya dan apa yang dikerjakannya

Berdasarkan dari 2 (dua) pendapat tokoh di atas maka aspek-aspek konsep diri membaca yang peneliti gunakan dalam mengukur konsep diri membaca adalah aspek-aspek konsep diri menurut Chapman dan Tunmer (1995) yaitu aspek; kompetensi membaca, persepsi kesulitan membaca dan sikap membaca. Alasan peneliti memilih aspek-aspek karena menurut peneliti penjabaranya sederhana namun memuat penjelasan yang mudah dipahami serta menurut peneliti aspek tersebut lebih sesuai dalam mengukur kosep diri membaca dalam hal proses siswa membaca buku sehingga cocok untuk mengukur konsep diri membaca khususnya pada siswa sekolah dasar.

\section{Persepsi Keterlibatan Orang Tua dalam Pendidikan}

\section{Pengertian Persepsi Keterlibatan Orang Tua dalam Pendidikan}

Persepsi adalah proses pengorganisasian dan penafsiran stimulus dalam lingkungan dalam hal penilaian yang dilakukan individu baik itu penilaian positif maupun negatif terhadap suatu objek. (Atkinson dan Hilgart, 2002). Persepsi merupakan proses yang melibatkan pengindraan dengan diterimanya stimulus oleh individu (Walgito, 2010). Sabour (2013) mengatakan persepsi adalah proses menerima, menyeleksi, mengorganisasikan, menyeleksi, mengartikan, menguji, dan memberikan reaksi kepada rangsangan panca indra. Menurut Walgito (2010), Objek persepsi dikelompokkan menjadi dua yaitu, objek manusia dan non-manusia. Objek persepsi manusia disebut person perception atau social perception sedangkan untuk objek non manusia disebut non-social perception atau things perception. 
Robbins (2002) menambahkan bahwa persepsi positif merupakan penilaian individu terhadap suatu objek atau informasi dengan pandangan yang positif atau sesuai dengan yang diharapkan dari objek yang dipersepsikan atau dari aturan yang ada. Sedangkan, persepsi negatif merupakan persepsi individu terhadap objek atau informasi tertentu dengan pandangan yang negatif, berlawanan dengan yang diharapkan dari objek yang dipersepsikan atau dari aturan yang ada.

Berdasarkan pengertian persepsi menurut para ahli diatas maka dapat disimpulkan bahwa persepsi adalah suatu proses pengorganisasian dan menginterpretasikan terhadap suatu objek atau stimulus yang diterima baik secara positif maupun negatif oleh individu dari lingkungan sekitar. Dalam penelitian ini persepsi dilekatkan pada keterlibatan orang tua dalam pendidikan artinya bahwa hal ini berkaitan dengan penilaian atau interpretasi dari para siswa terhadap orang tuanya dalam hal keterlibatan orang tua dalam membaca.

Kajian yang dilakukan oleh penulis berfokus pada keterlibatan orang tua dalam pendidikan. Hill dan Tyson (2009) mengungkapkan pengertian keterlibatan orang tua dalam pendidikan adalah bentuk interaksi orang tua dengan pihak sekolah dan interaksi antara orang tua dengan siswa di rumah dalam rangka mencapai kesuksesan akademik siswa. Grolnick dan Slowiaczek (1994) mendefinisikan keterlibatan orang tua dalam pendidikan adalah partisipasi orang tua melalui sumber daya yang diberikan dalam bentuk perilaku, kognitif/intelektual dan pribadi dalam proses belajar anak secara dominan. Hornby (2011) mendefinisikan keterlibatan orang tua dalam pendidikan adalah bentuk partisipasi orang tua dalam proses dan pengalaman pendidikan anak-anak mereka. Padavick (2009), mengungkapkan bahwa keterlibatan orang tua dalam pendidikan adalah partisipasi orang tua terhadap pendidikan dan pengalaman dalam belajar siswa baik di 
sekolah maupun di tempat lain yang dapat mendukung kemajuan siswa. Lall, Campbell dan Gillborn (2004) memberi pengertian keterlibatan orang tua dalam pendidikan sebagai perilaku pengasuhan di rumah dalam hal ini termasuk penyediaan lingkungan yang aman dan stabil, stimulasi intelektual, diskusi antara orang tua dengan anak dan kegiatan orang tuan untuk ikut serta dalam partisipasi dalam kegiatan sekolah dengan menjalin komunikasi yang baik dengan pihak sekolah.

Korfmacher, dkk (2008) mengartikan keterlibatan orang tua dalam pendidikan merupakan proses menghubungkan orang tua dengan program sekolah dan menggunakan layanan program untuk kemampuan terbaik orang tua dan program sekolah. Epstein (2005) berpendapat bahwa keterlibatan orang tua adalah sebuah bentuk tanggung jawab orang tua terhadap anaknya di rumah, di sekolah maupun di masyarakat yang diwujudkan dalam bentuk kerja sama, berbagi informasi, membimbing, memecahkan masalah dan meraih keberhasilan.

Berdasarkan beberapa penjelasan diatas maka dapat disimpulkan bahwa persepsi terhadap keterlibatan orang tua dalam pendidikan adalah penilaian siswa terhadap keterlibatan orang tua dalam proses interaksi orang tua dengan pihak sekolah dan interaksi orang tua dengan siswa di rumah dalam rangka mencapai kesuksesan akademik dalam pendidikan.

\section{Aspek - Aspek Persepsi Keterlibatan Orang Tua dalam Pendidikan}

Aspek persepsi keterlibatan orang tua dalam kajian ini menggunakan aspek-aspek dari objek persepsi dalam hal ini adalah aspek keterlibatan orang tua dalam pendidikan menurut Hill dan Tyson (2009) sebagai berikut:

a. Home-based Involvement (keterlibatan dirumah)

Keterlibatan orang tua di rumah dengan melakukan kegiatan untuk mendukung kesuksesan 
akademik, seperti berkomunikasi dengan anak mengenai aktivitas belajar di sekolah, mendampingi anak belajar di rumah, menciptakan lingkungan belajar yang nyaman, menyediakan buku-buku bacaan dalam belajar.

b. School-based involvement (keterlibatan di sekolah)

Orang tua terlibat dengan sukarela berpartisipasi di acara sekolah, menjalin komunikasi dengan guru dan bekerja sama dengan pihak sekolah untuk mendukung kesuksesan akademik anak.

c. Academic socialization (sosialisasi akademik)

Orang tua memberikan informasi-informasi seputar strategi dan cara-cara belajar untuk membuat anak lebih mandiri, berkembang kognitifnya dalam proses belajar sehingga anak sadar akan manfaat belajar untuk masa depan yang baik dengan dibantu oleh orang tua dalam menyiapkan masa depan anak tersebut. Dalam hal ini orang tua mendorong anak untuk berkembang dalam proses belajar berdasarkan motivasi internal untuk mengenal dunia luar sehingga anak bisa lebih fokus kepada masa depannya.

Adapun aspek-aspek keterlibatan orang tua menurut Epstein (2005) antara lain:

a. Pengasuhan

Keterlibatan orang tua dalam bentuk pengasuhan yang dimaksud adalah bagaimana cara orang tua memberikan kenyamanan bagi siswa pada saat di rumah. Orang tua dapat melakukan pembimbingan, perhatian dalam kesehatan dan pembinaan berdasarkan latar belakang keluarga.

b. Komunikasi (communicating)

Keterlibatan orang tua dalam bentuk komunikasi ini berupa keterlibatan orang tua dalam komunikasi tentang proses dan perkembangan pendidikan siswa baik di sekolah maupun di rumah. 
c. Sukarelawan (Volunteering)

Keterlibatan orang tua dalam bentuk volunteer atau sukarelawan ini berupa bantuan dan dukungan orang tua secara langsung pada kegiatan pembelajaran siswa di sekolah maupun di rumah.

d. Pembelajaran di rumah (Learning at home)

Keterlibatan orang tua dalam pembelajaran di rumah (learning at home) adalah bagaimana orang tua (ibu) memberikan dukungan, bantuan maupun semangat kepada siswa ketika berada di rumah dalam proses belajar.

e. Membuat keputusan (decision making)

Keterlibatan orang tua dalam pengambilan keputusan (decision making) yaitu orang tua membantu siswa dalam proses pengambilan keputusan serta memberikan saran. Bentuk decision making meliputi: membantu siswa dalam menyelesaikan masalah dan memberikan informasi mengenai bagaimana menyelesaikan tugas.

Berdasarkan pendapat di atas, disimpulkan bahwa aspek-aspek keterlibatan orang tua dalam pendidikan menurut Hill dan Tyson (2009) yaitu Home-base involvement (keterlibatan di rumah), School-base Involvement (keterlibatan di sekolah), dan Academic socialization (sosialisasi akademik). Epstein (2005) menyatakan aspek keterlibatan orang tua meliputi aspek Parenting, Komunikasi, sukarelawan, pembelajaran di Rumah dan membuat keputusan.

Pada kajian ini, aspek-aspek Keterlibatan orang tua dalam pendidikan yang digunakan oleh peneliti yaitu Homebase involvement (keterlibatan di rumah), School-base involvement (keterlibatan di sekolah), dan Academic socialization (sosialisasi akademik). Peneliti memilih aspek tersebut karena aspek dari Hill dan Tyson (2009) lebih spesifik dan praktis dalam menjelaskan keterlibatan orang tua dalam pendidikan khususnya membaca pada anak SD. 


\section{BAB III. \\ HUBUNGAN KONSEP DIRI \\ MEMBACA DAN PERSEPSI ORANG TUA TERHADAP MINAT BACA}

\section{A. Hubungan Antara Konsep Diri Membaca Dengan Minat Baca}

Konsep diri sendiri terbentuk dari berbagai kesan yang diterima oleh seseorang (Dayakisni, 2006). Persepsi diri pada perilaku khusus mempengaruhi konsep diri sub area (seperti matematika, penelitian sosial) yang kemudian akan mengacu pada konsep diri akademik. Konsep diri dalam kegiatan membaca merupakan suatu bagian dari konsep diri akademik yang dalam hal ini mencakup persepsi kompetensi membaca, persepsi kesulitan membaca serta sikap terhadap membaca (Chapman dan Tunmer, 1995) . Konsep diri memiliki hubungan dengan minat baca siswa. Hal ini dibuktikan dengan hasil penelitian bahwa konsep diri mempengaruhi perilaku membaca siswa (Melekoğlu dan Wilkerson, 2011).

Aspek persepsi kompetensi membaca berpengaruh pada aspek perhatian dalam minat baca. Hal ini berkaitan tentang gambaran diri anak yang akan membentuk citra diri dalam menilai kemampuannya dalam membaca yang akan berpengaruh pada minat dan prestasi membaca. (Chapman dan Tunmer 1995). Hal diatas Senada dengan pendapat Rahim (2008) yang menyatakan bahwa salah satu ciri individu yang memiliki minat baca yang kuat adalah selalu berusaha untuk mendapatkan bahan bacaan dan kemudian membacanya atas kesadaran, perhatian dan kemauan sendiri berdasarkan kemampuan atau kompetensi membaca yang baik dalam dirinya. Sehingga jika anak memiliki persepsi kompetensi membaca yang positif/baik maka akan membentuk atensi yang baik dalam membaca sehingga minat baca menjadi tinggi.

Aspek persepsi kesulitan membaca berkaitan dengan minat baca anak. Hal ini mengacu pada keyakinan bahwa kegiatan membaca itu memiliki tingkatan kesulitan. Sehingga dengan persepsi anak terhadap dirinya dalam kesulitan 
membaca akan menjadi motivasi bagi anak untuk menghadapi kesulitan membaca sehingga anak terus membaca berulangulang untuk memahami maksud dari bacaan. Hal ini berkaitan dengan aspek frekuensi dalam membaca. Sehingga hal tersebut juga akan memunculkan atensi atau perhatian anak dalam membaca. Setiap anak mmiliki perbedaan persepsi terhadap kesulitan membaca, karena anak-anak dapat memegang persepsi diri yang positif maupun negatif tentang kesulitan membaca suatu bacaan (Nicholls dan Miller, 1984).

Oleh karena itu sangat penting persepsi anak terhadap kesulitan membaca sehingga akan menstimulasi anak untuk terus membaca sehingga anak memusatkan perhatian penuh untuk menyelesaikan kesulitan tersebut. Anak-anak yang mengalami kesulitan membaca dapat menunjukkan persepsi kesulitan yang tinggi dalam membaca dan persepsi kemampuan membaca yang tinggi. Persepsi kesulitan membaca cenderung berkorelasi lebih tinggi dengan kinerja membaca. (Butler, 1990); (Nicholls dan Miller, 1984). Dari uraian diatas dapat disimpulkan bahwa persepsi kesulitan membaca memiliki hubungan dengan aspek frekuensi dan perhatian dalam membaca semakin tinggi persepsi kesulitan membaca maka semakin tinggi minat baca anak dalam menyelesaikan tugas membaca tersebut.

Aspek sikap membaca merupakan sub-komponen konsep diri yang penting dalam membaca. Sikap ini mengacu pada komponen afektif konsep diri membaca, yang didefinisikan dalam hal perasaan untuk membaca. Sikap membaca memiliki hubungan dengan aspek rasa senang dalam minat baca. Smith (1991) menjelaskan bahwa sikap dalam membaca dapat dilihat dari kesiapan siswa dalam wujud suka atau tidak suka saat akan melakukan aktivitas membaca. Sikap Positif dalam membaca akan memberikan pengaruh pada kesenangan dan kegemaran siswa dalam membaca yaitu perasaan menyenangkan dalam membaca bahwa sikap positif dalam kegiatan membaca akan meningkatkan intensitas perasaan atau kesenangan yang tinggi dalam membaca. Ajzen 
(1980) menambahkan sikap sebagai disposisi belajar tentang cara berperilaku, baik negatif atau positif dan sikap membaca menunjuk pada sifat seseorang terhadap membaca sebagai kegiatan yang menimbulkan kesenangan saat melakukan kegiatan membaca. Sehingga Sikap membaca yang positif dapat menginspirasi pengalaman membaca yang positif yang berimplikasi kepada perasaan yang senang setiap membaca buku.

Kraayenoord dan Schneider (1999) menunjukkan bahwa beberapa variabel motivasi seperti konsep diri membaca dan persepsi membaca memiliki hubungan terhadap minat baca pada siswa sekolah dasar kelas 3 dan 4 . Konsep diri membaca siswa berhubungan dengan minat membaca siswa. Siswa kelas 3 yang memiliki minat baca tinggi memiliki konsep diri membaca yang positif, Adapun siswa kelas 4 yang memiliki konsep diri membaca yang positif akan mempunyai minat yang tinggi pula terhadap membaca. Ketika siswa memiliki konsep diri terhadap membaca yang negatif, maka siswa tersebut akan memiliki minat baca yang rendah pula. Sebaliknya jika siswa memiliki konsep diri membaca yang positif maka siswa akan memiliki minat membaca yang tinggi dalam proses belajar.

Penelitian yang dilakukan oleh Viljantra, dkk (2016) menunjukkan hasil yang berbeda dari penelitian sebelumnya bahwa siswa dapat memiliki konsep diri membaca yang positif namun dapat memiliki minat baca yang rendah dan sebaliknya siswa dapat memiliki konsep diri membaca negatif namun memiliki minat baca yang tinggi.

Berdasarkan uraian di atas dapat disimpulkan bahwa konsep diri memiliki hubungan positif dengan minat baca pada siswa. Semakin positif konsep diri maka akan semakin tinggi minat baca pada siswa tersebut. Sebaliknya, semakin negatif, akan semakin rendah pula minat membaca pada siswa. 


\section{B. Hubungan Antara Persepsi Keterlibatan orang tua dalam pendidikan dengan Minat Baca}

Manusia adalah makhluk sosial yang tidak bisa hidup sendiri dan saling membutuhkan keberadaan orang lain di sekitarnya. Dalam melakukan interaksi sosial tersebut manusia saling tolong menolong, baik tolong menolong dengan materi, tenaga dan bahkan pikiran sehingga ada timbal balik dukungan sosial dari lingkungannya. Begitupun ketika individu berada dalam lingkungan keluarga, khususnya bagi anak akan membutuhkan keterlibatan orang tua salah satunya dalam membentuk budaya membaca dalam arti luas memerlukan proses, dan tidak bisa dilakukan secara instant. Perlu memberdayakan keterlibatan orang tua dalam pendidikan untuk memonitor dan mendukung program membaca dan literasi sekolah saat siswa ada di rumah. Keterlibatan orang tua dalam pendidikan memberikan kontribusi terhadap pembelajaran siswa (Cotton dan Wikelund 1989). Hill dan Tyson (2009), mengungkap keterlibatan orang tua dalam pendidikan adalah bentuk interaksi orang tua dengan pihak sekolah dan interaksi antara orang tua dengan siswa di rumah dalam rangka mencapai kesuksesan akademik siswa. Keterlibatan orang tua dalam pendidikan adalah partisipasi orang tua melalui sumber daya yang diberikan dalam bentuk perilaku, kognitif/intelektual dan pribadi dalam proses belajar anak secara dominan (Grolnick dan Slowiaczek, 1994).

Pada aspek home-based involvement (keterlibatan dirumah) berpengaruh pada aspek kesadaran dan rasa senang dalam minat baca siswa. Santrock (2007) yang menyatakan bahwa hubungan yang dekat dengan orang tua penting dalam perkembangan anak, karena hubungan itu berfungsi sebagai contoh atau cetakan yang akan dibawa terus dari waktu ke waktu untuk mempengaruhi pembentukan hubungan baru. Jika anak merasa senang dan nyaman berada di dekat orang tua, ia akan berusaha untuk selalu dekat dengan orang tua nya dan apapun yang dilakukan orang tua, anak juga ingin melakukannya dengan kesadaran dan rasa senang terhadap suatu minat anak dalam suatu kegiatan. 
Hal ini sesuai dengan pendapat Mowb \& Young (Yetti, 2009) yang menyatakan bahwa kegiatan belajar di rumah yaitu membaca bersama-sama antara orang tua dan anak akan berpengaruh terhadap sikap dan minat membaca anak. Proses membentuk kebiasaan membaca diperlukan keterlibatan orang tua baik di rumah atau sekolah. Ketika anak-anak menganggap model (orang tua) memiliki keterampilan dan kemampuan membaca, hal ini akan memberikan dampak baik yang signifikan dan kuat untuk anak dalam membangun kesadaran dalam membaca (Bandura, 1986). Sehingga, dapat disimpulkan bahwa orang tua memiliki peran untuk terlibat di rumah dalam mendampingi anak belajar khususnya mencontohkan kegiatan membaca, yang akan diikuti pula oleh anak-anak dan hal tersebut dapat meningkatkan minat baca pada anak. Cotton dan Wikelund (1989) menyatakan bahwa program keterlibatan orang tua yang paling efektif adalah keterlibatan orang tua secara langsung berhubungan dengan aktivitas anak belajar di rumah (learning at home). Program yang melibatkan orang tua untuk membaca bersama siswa, membantu menyelesaikan pekerjaan rumah, membantu belajar berdampak pada hasil yang sangat memuaskan.

Aspek school-base involvement (keterlibatan di sekolah), orang tua terlibat dalam partisipasi kegiatan di sekolah (mis. menghadiri konferensi orang tua-guru dan sekolah) kegiatan). Perilaku orang tua dalam aspek keterlibatan di sekolah ini juga akan mempengaruhi minat baca pada anak yaitu pada aspek kesadaran dan rasa senang dalam membaca buku. Suntrok (2007) menjelaskan bahwa kesenangan terhadap suatu aktivitas berkaitan dengan sisi afektif yang nampak dalam rasa suka atau tidak senang dan kepuasan pribadi terhadap objek tersebut. Dapat disimpulkan bahwa keterlibatan orang tua di sekolah memberikan dampak dan pengaruh positif dalam meningkatkan minat baca siswa.

Aspek academic socialization (sosialisasi akademik) berupa Strategi yang dilakukan orang tua untuk membuat anak lebih mandiri, berkembang kognitif nya dalam proses belajar 
sehingga anak sadar akan manfaat belajar memiliki pengaruh terhadap aspek perhatian dan kesadaran dan frekuensi membaca dalam minat baca. Dalam hal ini, orang tua memberikan kegiatan yang merangsang secara intelektual/ kognitif pada anak seperti pergi ke perpustakaan dan berbicara tentang bacaan-bacaan terkini, latihan membaca dan membacakan bacaan untuk anak-anak. Sehinga hal tersebut akan merangsang kognitif dan anak akan menaruh dan perhatian dan kesadaran akan manfaat membaca buku dalam aktivitas belajar (Slowiaczek dan Grolnick, 1994). Hal ini sejalan dengan Sebuah studi longitudinal lima tahun tentang keterlibatan orang tua dalam pengembangan kognitif membaca anak-anak yang dilakukan oleh Senechal dan Lefevre (2010) melaporkan bahwa saat orang tua membantu anak dalam membaca dan menjelaskan isi dan manfaat dari membaca secara positif mempengaruhi kelancaran membaca anak-anak sehingga anak-anak akan lebih sering membaca buku karena orang tua terlibat di dalam proses belajar anak. Hal ini sejalan dengan pendapat Epstein (2005) bahwa keterlibatan orang tua dalam proses belajar di rumah (learning at home) adalah bagaimana orang tua menunjukkan perilaku seperti memberikan dukungan, bantuan maupun semangat kepada siswa ketika berada di rumah dalam proses belajar. Sehingga dari urian diatas dapat disimpulkan bahwa perilaku orang tua yang mendukung aktivitas membaca pada anak akan mempengaruhi minat baca anak.

Dari uraian diatas menunjukkan bahwa orang tua harus terlibat untuk mengomptimalkan kemampuan kognitif/ intelektual mereka dalam melatih anak-anak mengembangkan kemampuan dan minat baca sehingga anak- anak akan lebih sering membaca karena kesadaran membaca yang tinggi.

Keterlibatan orang tua dalam pendidikan memiliki hubungan dengan minat baca pada siswa. Dalam hal ini persepsi siswa memainkan peran penting dalam memersepsikan keterlibatan orang tua dalam kegiatan membaca. Hal ini dibuktikan melalui penelitian yang dilakukan oleh Fakhriyah 
(2018) bahwa ada hubungan positif antara persepsi keterlibatan orang tua dengan minat baca siswa sekolah dasar. Hal ini senada dengan hasil penelitian Klauda (2008) mengenai persepsi siswa mengenai keterlibatan orang tua serta teman dalam membaca yang berhubungan dengan motivasi dan kebiasaan membaca, dalam hal ini persepsi siswa terhadap keterlibatan orang tua memiliki hubungan dengan minat siswa sehingga apabila persepsi siswa terhadap keterlibatan orang tua positif maka siswa akan memiliki minat yang tinggi. Semakin Positif persepsi siswa terhadap keterlibatan orang tua maka semakin tinggi minat baca siswa. Senada dengan penelitian di atas, Penelitian yang dilakukan oleh Kitmachi (2014) dengan judul peran keterlibatan orang tua dalam proses membaca pada anak menunjukkan bahwa orang tua yang terlibat di lingkungan keluarga dalam proses belajar anak khususnya dalam membaca mempengaruhi motivasi membaca anak dan kemampuan membaca yang berkaitan dengan minat.

Hill dan Tyson (2009) menjelaskan bahwa keterlibatan orang tua dalam pendidikan dapat diwujudkan dalam berbagai bentuk aktivitas yang dilakukan oleh orang tua melalui kerja sama dengan guru baik di rumah atau di sekolah, guna memaksimalkan perkembangan dan pendidikan anak di sekolah demi keuntungan mereka, anak dan program sekolah. Hal tersebut sangat penting bagi kesinambungan antara pendidikan di rumah dan di sekolah. Pelaksanaan keterlibatan orang tua sendiri sangat memerlukan kesadaran dan upaya dari orang tua terlebih lagi pihak sekolah, karena orang tua akan terlibat dengan aktif apabila sekolah berusaha untuk memberikan rasa nyaman bagi orang tua. (Diadha, 2015)

Berdasarkan uraian di atas dapat disimpulkan bahwa Persepsi keterlibatan orang tua dalam pendidikan memiliki hubungan positif dengan minat baca pada siswa. Semakin positif Persepsi keterlibatan orangmu maka akan semakin tinggi minat baca pada siswa tersebut. Sebaliknya, semakin negatif persepsi keterlibatan orang tua, akan semakin rendah pula minat membaca pada siswa. 


\section{Hubungan Antara Konsep Diri Membaca dan Persepsi Keterlibatan Orang Tua dalam Pendidikan Dengan Minat Baca}

Minat besar pengaruhnya terhadap aktivitas dalam membaca. Tanpa minat seseorang tidak akan melakukan perilaku membaca. Minat merupakan salah satu faktor untuk meraih sukses dalam belajar dan belajar yang dilakukan salah satunya melalui membaca. Menurut Harris dan Sipay (Nursalina, 2014) minat membaca akan nampak dengan ciri-ciri perasaan senang atau tertarik, dan perhatian dalam membaca.

Konsep diri memiliki kaitannya dengan minat baca. Banyak faktor-faktor yang mempengaruhi minat baca. Salah faktor tersebut adalah konsep Diri (Denessen, Ecless dan Zareet, 2007). Penelitian yang dilakukan oleh (Denessen, Ecless dan Zareet, 2007) mengenai Hubungan longitudinal antara konseps diri, minat dalam belajar serta prestasi akademik bahwa konsep diri berkorelasi positif dalam minat siswa dalam hal ini salah satunya adalah minat dalam membaca yang tertuang dalam aktivitas belajar. Hurlock (2004) mengatakan bahwa konsep diri anak yang dibentuk sejak dini akan membantu anak-anak tersebut menumbuhkan minat terhadap sesuatu pelajaran. Konsep diri akan memberikan kerangka acuan yang mempengaruhi manajemen diri terhadap situasi dan terhadap orang lain. Konsep diri ada yang sifatnya positif dan negatif. Individu yang memiliki konsep diri negatif meyakini dan memandang dirinya lemah, tidak dapat berbuat, tidak kompeten, gagal, tidak menarik, tidak disukai dan kehilangan daya tarik terhadap hidup. Individu akan cenderung bersikap pesimistis terhadap kehidupan dan kesempatan yang dihadapinya. Sebaliknya individu dengan konsep diri positif akan mampu menghargai dirinya dan melihat hal-hal positif yang dapat dilakukannya demi keberhasilan dan prestasi (Wahyuni, 2007). Hal ini juga di dukung oleh penelitian yang dilakukan oleh Fakhriya (2018) bahwa ada hubungan antara konsep diri dengan minat baca pada siswa sekolah dasar. 
Minat baca tidak timbul dengan sendirinya, akan tetapi dipengaruhi oleh berbagai faktor eksternal, dan salah satunya adalah faktor keterlibatan orang tua . Lamb \& Arnold (dalam Rahim, 2008) mengatakan bahwa minat baca dipengaruhi oleh faktor lingkungan yaitu lingkungan keluarga. Keterlibatan orang tua adalah partisipasi orang tua melalui sumber daya yang diberikan dalam bentuk perilaku, kognitif/intelektual dan pribadi dalam proses belajar anak secara dominan. (Grolnick dan Slowiaczek, 1994).

Seorang anak belajar mengenai sesuatu dari lingkungan sekitarnya. Mereka mengembangkan kemampuan kognitif nya dengan cara berinteraksi dengan orang di sekitarnya (Santrock, 2013). Lingkungan primer yang pertama kali dikenal oleh anak adalah lingkungan keluarga. Maka dari itu, peran dan keterlibatan orang tua penting untuk menumbuhkan kemampuan kognitif nya dalam perkembangan literasi salah satunya yaitu membaca. Dibutuhkan stimulasi-stimulasi dari orang tua untuk menumbuhkan kemampuan literasi anak. Orang tua yang memberikan stimulasi dini pada perkembangan literasi anak cenderung memiliki kepercayaan peda kegiatan membaca.

Orang yang paling berpengaruh untuk menumbuhkan minat baca anak adalah orang tua. minat tumbuh dari dalam diri sendiri yang menjadi sebuah kebiasaan. Peranan orang tua sangat penting dalam hal menumbuhkan minat baca. Orang tua terlibat sebagai tokoh panutan atau model yang menyukai aktivitas membaca yaitu senang dan gemar membaca bersamasama anak. Selain itu peran orang tua dalam menumbuhkan minat baca yaitu orang tua memperkenalkan anak dengan buku-buku bacaan di rumah, menyediakan sumber-sumber bacaan yang banyak $d$ rumah ataupun orang tua mengajak anak-anak mengunjungi toko buku atau perpustakaan. (Bangsawan, 2018)

Anak dengan latar belakang orang tua yang percaya bahwa dengan melakukan kegiatan membaca sejak usia anakanak akan tumbuh menjadi seorang pembaca yang aktif 
(Ghoting dan Martin-Diaz, 2006). Keterlibatan orang tua yang diterima dan dirasakan siswa akan membangkitkan semangat untuk melakukan kegiatan membaca. Dengan adanya keterlibatan orang tua dalam aktivitas membaca berupa parenting, komunikasi, volunteering, belajar di rumah dan berkolaborasi dengan masyarakat. Dalam hal ini beberapa kegiatan yang dapat dilakukan oleh orang tua di rumah adalah seperti, membaca bersama, menyediakan berbagai macam buku bacaan, memberikan anak waktu untuk membaca dan lain sebagainya (Hornby, 2011). Dengan adanya keterlibatan orang tua yang berupa menyediakan buku-buku bacaan, majalah, koran yang tersedia di rumah, akan menimbulkan minat dalam membaca siswa.

Berdasarkan dinamika di atas maka peneliti menduga bahwa minat baca siswa dapat diprediksi oleh faktor internal yaitu konsep diri membaca dan faktor eksternal yaitu persepsi keterlibatan orang tua dalam pendidikan secara bersama-sama. Adanya dorongan dari dalam siswa dan adanya keterlibatan orang tua dalam pendidikan akan memberikan dampak positif, yaitu membuat siswa terdorong untuk selalu mengulangi kegiatan membaca secara kontinu. Konsep diri merupakan faktor dari dalam diri siswa dan keterlibatan orang tua merupakan faktor dari luar yang mempengaruhi siswa dalam kegiatan membaca sehingga kedua hal itu yaitu konsep diri membaca dan persepsi keterlibatan orang tua dalam pendidikan akan secara bersama-sama mempengaruhi minat baca pada siswa. 


\section{BAB V \\ PENUTUP}

Berdasarkan hasil kajian pada bab-bab sebelumnya, maka dapat diambil kesimpulan sebagai berikut; (1) ada hubungan positif antara konsep diri membaca dengan minat baca. Semakin positif konsep diri membaca maka semakin tinggi minat baca. Sebaliknya, semakin negatif konsep diri membaca maka semakin rendah minat baca. Besarnya sumbangan efektif konsep diri membaca dengan minat baca sebesar $73,1 \%$, dan sisanya sebesar $26,9 \%$ dipengaruhi oleh variabel lain yang tidak diteliti. (2) ada hubungan positif antara persepsi keterlibatan orang tua dalam pendidikan dengan minat baca. Semakin positif persepsi keterlibatan orang tua dalam pendidikan maka semakin tinggi pula minat baca. Sebaliknya, semakin negatif persepsi keterlibatan orang tua dalam pendidikan maka semakin rendah minat baca.. Sumbangan efektif persepsi keterlibatan orang tua dalam pendidikan dengan minat baca adalah $46,1,6 \%$ sedangkan $53,9 \%$ ditentukan oleh variabel lain tidak diukur dalam kajian ini. (3) ada hubungan antara konsep diri membaca dan persepsi keterlibatan orang tua dalam pendidikan secara bersama-sama dengan minat baca. Sumbangan efektif persepsi keterlibatan orang tua dalam pendidikan dan konsep diri membaca secara bersamasama dengan minat baca adalah 75,5\% sedangkan 24,5\% ditentukan oleh variabel lain tidak diukur dalam kajian ini.

Dengan adanya temuan pada kajian ini, sekolah diharapkan mampu untuk menumbuhkan dan meningkatkan minat baca dengan cara membentuk konsep diri membaca yang positif sejak di sekolah dasar dengan membiasakan siswa-siswi melalui kegiatan-kegiatan seperti lomba membaca buku, lomba mendongeng dll dengan memberikan reward jika siswa berhasil dalam membaca, jika belum berhasil diberikan punishment positif agar siswa terus belajar mejadi yang terbaik dalam hal membaca. Selain itu sekolah dapat melakukan sosialisasi dengan orang tua 
siswa akan pentingnya keterlibatan orang tua dalam menumbuhkan minat baca siswa. Untuk itu bagi sekolah perlu diperdalam dan menjalankan program literasi yang dikembangkan di sekolah, hal ini urgen untuk disosialisasikan kepada orang tua sehingga orang tua bisa memahami program yang didapatkan oleh anak mereka di sekolah, sehingga mereka memahami bagaimana berkontribusi untuk mendukungnya. Partisipasi orang tua memerlukan perhatian khusus dan serius, karena pihak sekolah harus mampu menyesuaikan waktu, keahlian, pengalaman, dan ketersediaan maupun memastikan bahwa benar adanya komitmen orang tua dengan program literasi salah satunya budaya membaca yang dikembangkan di sekolah. Sehingga, disarankan agar melalui pihak sekolah juga bisa berkolaborasi dengan Dinas Pendidikan setempat memberikan orientasi kepada pihak sekolah-sekolah tentang perlunya sistem manajemen pendidikan dengan melibatkan orang tua dalam proses tersebut.

Guru diharapkan untuk mampu membuat siswa/i sejak SD untuk gemar membaca dan menciptakan budaya membaca melalui metode-metode kreatif pembelajaran yang merangsang anak untuk memiliki minat baca, pertama metode" Games Book" merupakan salah satu media pembelajaran bisa diterapkan dan digunakan guru SDN Triharjo dalam mengajarkan materi kepada siswa melalui permainan. Permainan terselip dalam sebuah buku yang di dalamnya terdapat variasi permainan yang memungkinkan siswa tertarik dan mengikutinya. Games Book memberikan alternatif baru dalam meningkatkan minat dan aktivitas baca. Kedua, Selain itu guru bisa menerapkan metode "diagram wartawan" yaitu Setiap siswa diwajibkan untuk membaca buku dari perpustakaan sekolah. Setelah selesai membaca, ada sesi tertentu bagi siswa untuk mempresentasikan ilmu apa yang didapatnya dari buku tersebut. Setelah itu muridmurid yang lainnya akan berperan sebagai wartawan untuk bertanya kepada siswa yang sudah selesai membaca terkait apa yang sudah didapat dari hasil bacaan tersebut. Ketiga guru bisa menerapkan Metode inquiry merupakan metode yang menuntut 
peserta didik secara aktif dan sistematik mencari jawaban dari suatu permasalahan, menemukan pemecahan masalah yang dihadapi dengan penuh kemandirian sehingga siswa terpacu untuk membaca buku untuk menemukan solusi dari sebuah permasalahan.

Pada hasil kajian menunjukkan bahwa persepsi keterlibatan orang tua dengan minat baca berkorelasi positif dan signifikan dengan minat baca. Bagi orang tua untuk tetap mempertahankan terlibatnya dalam kegiatan membaca anak dengan terlibat di rumah, terlibat di kegiatan sekolah dan mempersiapkan masa depan anak dengan menyosialisasikan informasi tentang pengatahuan-pengatahuan seputar belajar dan bersama-sama dengan anak mempersiapkan diri lewat strategi belajar untuk kesuksesan akademik. Orang tua bisa terlibat lebih serius di rumah seperti mendampingi anak belajar, mengerjakan PR maupun komunikasi yang baik dengan anak saat belajar. Untuk aktivitas di sekolah orang tua bisa mengambil peran terlibat sebagai nara sumber dalam topik terkait dengan bidang kepakaran orang tua ataupun terlibat dalam kegiatan Family Day dimana semua orang tua secara sukarela hadir mendukung kegiatan Family Day di sekolah. 


\section{DAFTAR PUSTAKA}

Adam, A. (2017). Hubungan Minat Baca dengan Prestasi Belajar Bahasa Indonesia bagi Siswa Kelas VI SD Negeri 57 BuluBulu Kecamatan Marusu Kabupaten Maros. Jurnal Kajian Pendidikan Dasar, 2(2), 314-324.

Ajzen, I., \& Fishbein, M. (1980). Understanding Attitudes and Predicting Social Behavior.

Al-Ajami, H., \& Soeharto, T. N. E. D. (2014). Hubungan antara Persepsi Siswa tentang Kompetensi Pedagogik Guru dan Dukungan Sosial Orang tua dengan Motivasi Belajar pada siswa di Mts Ibadurrahman Tibu Sisok Desa Loafing Maka Lombok Tengah tahun ajaran 2013/2014. Jurnal SosioHumaniora, 5(2), 178-198.

Alexander, J. E., \& Filler, R. (1976). Attitudes and Reading. Newark, DE: International Reading Association.

Antari, D. N., Sundari, N., \& Wulan, N. S. (2016). Studi Deskriptif Minat Baca Siswa Sekolah Dasar Kelas V Di Kota Serang. Jurnal Antologi UPI, 4(2). 1-11

Atkinson, R.L., Atkinson, R.C. \& Hilgart, E.R. (2002). Pengantar Psikologi. Edisi kedepalan. Jakarta: Erlangga

Atmini, I. (2017). Hubungan Antara Dukungan Sosial Orang tua Dan Motivasi Berprestasi Dengan Minat Membaca Pada Siswa. (Tesis tidak dipublikasikan). Fakultas Psikologi Universitas Mercu Buana ,Yogyakarta.

Azwar, S. (2015). Metode penelitian. Yogyakarta : Pustaka Pelajar

Azwar, S. (2016a). Penyusunan Skala Psikologi. Yogyakarta : Pustaka Pelajar 
Azwar, S. (2016b). Reliabilitas dan Validitas. Yogyakarta : Pustaka Pelajar.

Azwar, S. (2017). Dasar-dasar Psikometrika. Yogyakarta : Pustaka Pelajar

Baharudin, \& Wahyuni, E. N. (2007). Teori Belajar dan Pembelajaran. Yogyakarta: Ar-Ruzz Media.

Baker, L., \& Scher, D., \& Mackler, K. (1997). Home and Family Influences on Motivations for Reading. Educational Psychologist, 32(2), 69-82

Bangsawan, I.R. (2018). Minat Baca Siswa. Sumatera Selatan : Dinas Pendidikan, pemuda olahraga dan pariwsata.

Berger, E. H. (2000). Parents as Partners in Education (5th ed). New Jersey: Prentice Hall.

Burn, R. B. (1993). Konsep diri : Teori, Pengukuran dan Perkembangan Perilaku. Alih bahasa : Eddy. Jakarta : Arcan.

Byrne, B. M. (1996b). Measuring Self-concept across the Life Span: Issues and instrumentation. American Psychological Association.

Calhoun, J.F. \& Accocella, J.R. (1995). Psikologi tentang Penyesuaian dan Hubungan Kemanusiaan. Edisi III. Diterjemahkan oleh Satmoko. Semarang : IKIP Semarang Press.

Central Connecticut State University. (2016). World's Most Literate Nations ranked. Diunduh dari https://webcapp.ccsu.edu/?

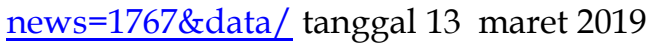

Chaplin, J.P. (2006). Kamus Lengkap Psikologi. Jakarta: PT Raja Grafindo Aksara. 
Chapman, J. W., \& Tunmer, W. E. (1995). Development of Young Children's Reading Self-Concepts: An Examination of Emerging Subcomponents and their Relationship with Reading Achievement. Journal of Educational Psychology, 87(1), 154-161

Chapman, J.W., Tunmer, W.E., \& Prochnow, J. E. (2000). Early Reading-Related Skills and Performance, Reading SelfConcept, and the Development of Academic Self-Concept: A Longitudinal Study. Journal of Educational Psychology, 92 (4), 703-708

Chen, S., Sun, H., Zhu, X., \& Chen, A. (2014). Relationship between Motivation and Learning in Physical Education and afterSchool Physical Activity. Research Quarterly for Exercise and Sport, 85(4), 468-477.

Conradi, K., Jang, B. G., \& Mc-Kenna, M. C. (2014). Motivation Terminology in Reading Research: A Conceptual Review. Educational psychology review, 26(1), 127-164.

Cotton, K., \& Wikelund, K. (1987). Parent Involvement in Education. United States: Office of Educational Research and Improvement (OERI).

Dalman, H. (2013). Ketrampilan Membaca. Jakarta : PT. Raja Grafindo Persada.

Darmono, (2007). Perpustakaan Sekolah: Pendekatan Aspek Manajemen dan Tata Kerja, Jakarta: Grasindo.

Dayakisni, T. (2006). Psikologi Sosial. Malang : UMM Press.

Diadha, R. (2015). Keterlibatan Orang tua dalam Pendidikan Anak Usia Dini di Taman Kanak-Kanak. Jurnal Edusentris, 2(1), 6171 
Denessen, J. J. A., Zarrett, N. R., \& Ecless, J. S. (2007). I Like to Do It, I'm Able, and I Know I Am: Longitudinal Couplings Between Domain-Specific Achievement, Self-Concept, and Interest. Child Development, 78(2), 430 - 447. doi: 10.1007/s10648-013-9245-z

Depdiknas. (2001). Kamus Besar Bahasa Indonesia. Jakarta : Balai Pustaka.

Eipstein, J. L., Sanders, M. G., \& Simon, B. S. (2002). School, Family and Community partnerships, your handbook for action: second edition. Thousand Oaks, California: Corwin Press.

Epstein, J.L., \& Salinas, K.C. (2004). Partnering with Families and Communities: Journal Educational Leadership, 61( 8), 12-18.

Erwina. (2014). Faktor-Faktor Dominan Yang Mempengaruhi Minat Baca Mahasiswa Survei Eksplanatori Tentang Minat Baca Mahasiswa Di Upt Perpustakaan Itb. Jurnal Kajian Informasi dan Kajian Perpustakaan. Vol. 1 (2).137 -142

Fakhriyah, D.S. (2018). Peran Persepsi Keterlibatan Ayah dan Keterlibatan Ibu serta Konsep Diri Membaca terhadap Minat Baca Siswa Sekolah Dasar. (Tesis tidak dipublikasikan). Fakultas Psikologi Universitas Gadjah Mada, Yogyakarta.

Ferara, M.M., \& Ferara, P.J. (2005). Parents as partners: Raising awareness as a teacher preparation program. The Clearing House, 79 (2), 77-82.

Ghoting, S. N., \& Martin-Diaz, P. (2006). Early literacy storytimes@ your library: Partnering with caregivers for success. American Library Association.

Ginting, V. (2005). Penguatan Membaca, Fasilitas Lingkungan Sekolah dan Keterampilan Dasar Membaca Bahasa 
Indonesia serta Minat Baca Murid. Jurnal pendidikan penabur, $4(4), 17-34$.

Grolnick, W. S., \& Slowiaczek, M. L. (1994). Parents' Involvement in Children's Schooling: A multidimensional onceptualization and motivational model. Child Development, 65(1), 237-252.

Grolnick, W. S., Benjet, C., Kurowski, C. O., \& Apostoleris, N. H. (1997). Predictors of Parent Involvement in Children's Schooling. Journal of Educational Psychology, 89(3), 538-546.

Harris A.J \& Sipay, E.R. (1980). How To in Increase Reading Ability, A Guide To Development and Remedial Methods. New York: Longman.

Heilman, A. W., Blair, T.R., \& Rupley, W.H. (1981). Principles and Practises in Teaching Reading. Columbus, Ohio: Merril Publishing Company.

Hill, N. E., \& Tyson, D. F. (2009). Parental involvement in middle school: a meta-analytic assessment of the strategies that promote achievement. Developmental psychology, 45(3), 740 750

Hoover-Dempsey \& Sandler. (2005). Final Performance Report for OERI Grant \# R305T010673: The Social Context of Parental Involvement: A Path to Enhanced Achievement. Project Monitor. Department of Psychology \& Human Development. Vanderbilt University

Hornby, G. (2011). Parental Involvement in Childhood Education: Building Effective School-Family Partnerships. Springer Science \& Business Media. 
Hornby, G., \& Blackwell, I. (2018). Barriers to parental involvement in education: an update. Journal of Educational , 70(1), 109119 .

Humas. (2016). 91,68 Persen Penduduk Indonesia Lebih Suka Menonton TV. Diunduh dari https://kulonprogokab.go.id/v3/portal/web/view_berita/ 4201/9168-Persen-Penduduk-Indonesia-Lebih-SukaMenonton-TV-daripada-Membaca tanggal 12 februari 2019

Hurlock, E.B. (2009). Psikologi Perkembangan : Suatu Perkembangan Sepanjang. Rentan Kehidupan. Jakarta : Erlangga.

Hurlock, E.B. (2013). Perkembangan anak. Jilid 2. Jakarta : Erlangga.

Kartika, E. (2010). Memacu Minat Membaca Siswa Sekolah Dasar. Jurnal Pendidikan Penabur, 3 (8), 113-128.

Kementerian Pendidikan dan Kebudayaan Republik Indonesia (2018). Seri pendidikan orang tua: Menumbuhkan minat baca anak [Parental education series - Fostering children's interest in reading]. Jakarta: Direktorat Pembinaan Pendidikan Keluarga.

Khairuddin, Z. (2013). A Study of Students' Reading Interests in a Second Language. International Education Studies, 6(11), 160170.

Kikas, E., Silinskas, G., Jogi, A. L., \& Soodla, P. (2016). Effects of Teacher's Individualized Support on Children's Reading Skills and Interest in Classrooms with different Teaching Styles. Learning and Individual Differences, 49 (1), 270-277.

Kimathi, H. K. (2014). Parental Involvement in Primary Standard three Pupils' Reading at Home in Igembe South 
Constituency, Meru County, Kenya. (Unpublished Masters Thesis), Kenyatta University.

Klauda, S.L.L. (2007). The Relations of Children Perceived Support For Recreational Reading From Parents and friends to Their Motivation For reading. (Unpublished Disertation). Faculty of the Graduate School of the University of Maryland

Korfmacher, J., Green, B., Staerkel, F., Peterson, C., Cook, G., Roggman, L., Faldowski, R.A. \& Schiffman, R. (2008). Parent Involvement in Early Childhood Home Visiting. Child $\mathcal{E}$ Youth Care Forum, 37(4), 171-196.

Kraayenoord, C.E., \& Schneider, W. E. (1999). Reading Achievement, Metacognition, Reading Self-concept and Interest: A study of German students in grades 3 and 4 . European Joumal Psychology of Education, 14(11), 305-324.

Kurniawai. (2009). Pengaruh Keterlibatan Orang Tua dan Kemampuan Ekonomi Keluarga terhadap Minat Baca Siswa Kelas Viiid Smp Negeri 1 Bojong Pekalongan. Tesis. Universitas Negeri Semarang.

Lall, M. C., Campbell, C., \& Gillborn, D. (2004). Parental Involvement in Education. Sheffield Hallam University. Educational policy Research unit.

Lerkkanen, M. K., Kiuru, N., Pakarinen, E., Viljaranta, J., Poikkeus, A. M., Rasku-Puttonen, H., \& Nurmi, J. E. (2012). The Role of Teaching Practices in The Development Of Children's Interest in Reading and Mathematics in Kindergarten. Contemporary Educational Psychology, 37(4), 266-279.

Marlina, L., Caska, C., \& Mahdum, M. (2017). Hubungan Minat Baca dan Motivasi Belajar dengan Hasil Belajar Ekonomi 
Siswa Kelas XI IPS Sman 10 Pekanbaru. Jurnal Pendidikan Ekonomi dan Bisnis, 9(1), 33-47.

Marsh, H.W. (1998). Age and Gender Effect in Physical Self concept for Adolescent Elite athlete and Nonatheletes : A multicohort - multioccasion design. Journal of Sport and Exercise Psychology, 20 (3), 277-259.

McBride, B. A., Schoppe, S. J., \& Rane, T.R. (2002). Child Characteristics, Parenting Stress and Parental Involvement: Fathers versus Mothers. Journal of Marriage and the Family, 64(2), 998-1011.

Miller, P. (2011). Theories of Developmental Psychology (5 ${ }^{\text {th }}$ Ed). USA: Worth Publisher

Melekoğlu, M. A \& Wilkerson, K.L. (2013). Motivation to Read: How Does It Change for Struggling Readers with and without Disabilities?. International Journal of Instructions, 6(1), 77-88.

Mokoagow, K. (2016). Peranan Surat Kabar dalam menumbuhkan Minat Baca Remaja di Kecamatan Singkil Kota Manado. Acta Diurna Komunikasi, 5(2), 1-6.

Morrison, G. S. (1988). Education and Development Of Infants, Todlers and Preschoolers. USA: Scott, Foresman.

Nicholls, J. G., Miller, A. T., \& Nicholls, J. G.(1984). Development and its discontents: The Differentiation of The Concept of Ability The Development of Achievement Motivation. CT JAI Press, 185(1), 218-223.

Noortyani, R. (2018). An Exploratory Study on Students' Reading Interest Development through Independent ReadingRetelling Activity. Arab World English Journal, 9 (2), 108 -117 
Nursalina, A. I., \& Budiningsih, T. E. (2014). Hubungan Motivasi Berprestasi dengan Minat Membaca Pada Anak. Educational Psychology Journal, 3(1), 1-7

Ormrod, J. E. (2009). Psikologi Pendidikan : Membantu Siswa Tumbuh dan Berkembang Jilid II. (A. Kumara, Penerj.) Jakarta: Penerbit Erlangga.

Padavick, J. F. (2009). Parental involvement with learning and increased student achievement. (unpublished Doctoral dissertation). Walden University.

Padavick, J.F. (2009). Parental Involvement with Learning and Increased Student Achievement (Education). proQuest Dissertations and Theses

Petty, W.T., \& Jensen, J.M. (1980). Developing Children's Language Massachussets: Allyn and Bacon Inc.

Priyatno, D. (2014). SPSS 22: Pengolahan Data Terpraktis. Yogyarkata : Penerbit Andi.

Puspitawati, H. (2012). Gender dan Keluarga: Konsep dan Realita di Indonesia. Bogor: PT IPB Press

Quandt, I., \& Selznick, R. (1984). Self-concept and Reading. Delaware: International Reading Association.

Rahim, F. A. (2008). Pengajaran Membaca di Sekolah Dasar. Jakarta: Bumi Aksara

Rahmi, R. (2019). Parental Involvement To Increase Children's Reading Interest For Preschool Children's Character Development. In International Conference on Early Childhood Education (pp. 435-444). 
Rakmat. J. (2008). Psikologi Komunikasi. Bandung: Remaja Rosda Karya.

Rider, N., \& Colmar, S. (2005). Reading Achievement and Reading Self-Concept In Year 3 Children. Australia: Association For Research in Education: NSW, COL05347.

Robbins, S. P. (2003). Perilaku Organisasi. Jakarta : PT Indeks Kelompok Gramedia.

Sabriyadi, S., Sumarna, N., \& Permana, T. (2015). Hubungan Antara Minat Baca Dengan Prestasi Belajar Pada Mata Pelajaran Produktif di SMK. Journal of Mechanical Engineering Education, 2(1), 124-129.

Sandjaja, W. (2005). Psikologi Pendidikan Siswa Tumbuh dan Berkembang. Jakarta: Kencana.

Santrock, J.W. (2003) Adolescence. Perkembangan Remaja. Edisi Keenam. Jakarta: Erlangga.

Santrock, W. J. (2007). Perkembangan Anak. Jakarta: Erlangga.

Sardiman, A,M. (2016). Interaksi dan Motivasi Belajar Mengajar. Jakarta : PT. Raja Grafindo

Sénéchal, M., \& LeFevre, J. A. (2010). Parental Involvement in The Development Of Children's Reading Skill: A five-year longitudinal study. Child development, 73(2), 445-460.

Slameto. (2015). Belajar dan Faktor-faktor yang Mempengaruhinya. Jakarta: PT.Raja Grafindo

Sobur, A. (2013). Psikologi Umum. Cetakan kelima. Jakarta: Pustaka Setia. 
Stoodt, B., Amspaugh, L., \& Hunt, J. (1996). Childrens Literature. USA : Gosuch Scarisbrick Publisher .

Suryabrata, S. (2016). Psikologi Pendidikan. Jakarta: PT. Raja Grafindo Persada

Susilowati, S. (2016). Meningkatkan Kebiasaan Membaca Buku Informasi pada Anak Sekolah Dasar. Jurnal Ilmiah Guru Caraka Olah Pikir Edukatif, 20(1), 1-8

Sutini. (2010). Upaya Meningkatkan Minat Baca Siswa Kelas III Sekolah Dasar. Jurnal Pendidikan Interaksi. 5(5), 56-64

Taringan, H. G. (2008). Membaca Sebagai Suatu Keterampilan Berbahasa. Bandung : Aksara.

Viljaranta, J., Kiuru, N., Lerkkanen, M. K., Silinskas, G., Poikkeus, A. M., \& Nurmi, J. E. (2017). Patterns of Word Reading Skill, Interest And Selfconcept of Ability. An International Journal of Experimental Educational Psychology. 37 (6), 712 -732. DOI: 10.1080/01443410.2016.1165798

Walgermo, B. R., Foldnes, N., Uppstad, P. H., \& Solheim, O. J. (2018). Developmental Dynamics of Early Reading Skill, Literacy Interest and Readers' Self-Concept within The First Year Of Formal Schooling. Reading and writing, 31(6), 13791399.

Walgito, B. (2010). Pengantar Psikologi Umum. Edisi kelima. Andi Offset: Yogyakarta.

Xia, T., Gu, H., \& Li, W. (2019). Effect of parents' encouragement on reading motivation: The mediating effect of reading selfconcept and the moderating effect of gender. Journal of Frontiers in Psychology, 10, 609. 
Yaumi, M. (2014). Pendidikan karakter: Landasan, pilar dan implementasi [Character education: Rationales, pillars, and implementation]. Jakarta: Prenadamedia Group.

Yetty, R. (2009). Pengaruh Keterlibatan Orang Tua dengan Minat Membaca anak ditinjau dari Pendekatan Stress Lingkungan. Jurnal ilmiah ilmu pendidikan. 9 (1), 17 -28

Yusuf, L.N. (2014) Psikologi Perkembangan Anak dan Remaja. Bandung : Rosdakarya 